LOCKHEED MATTIJ

ENVIRONMENTAL RESTORATION PROGRAM

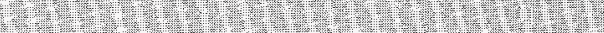

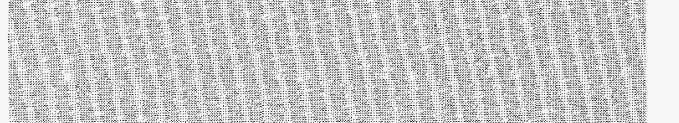
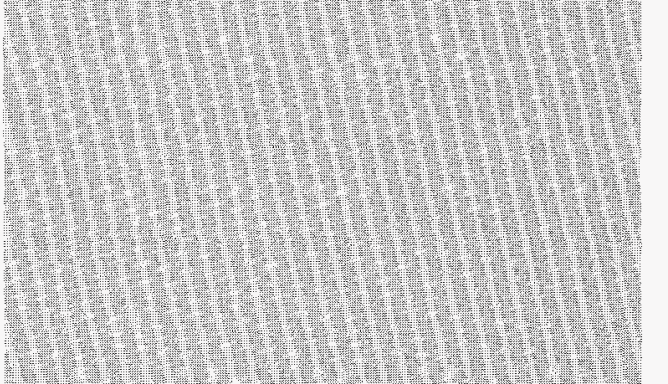

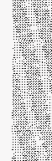
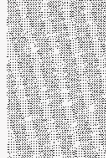

\section{$\sqrt{2}$}

(1)

(4).

(1).

(1)

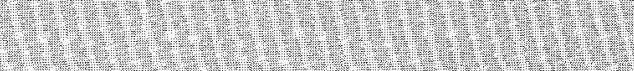

\section{Geological Mapping of the Oak Ridge K-25 Site, Oak Ridge, Tennessee}

$$
\begin{array}{r}
\text { P. J. Lemiszki } 120 \\
\text { AR } 151998 \\
\text { O STI }
\end{array}
$$


Environmental Restoration Program Division

K-25 Environmental Restoration Program

\title{
Geological Mapping of the Oak Ridge K-25 Site, Oak Ridge, Tennessee
}

\author{
P. J. Lemiszki
}

Date Issued_January 1994

\author{
Prepared by \\ Environmental Sciences Division \\ Oak Ridge National Laboratory \\ Oak Ridge, Tennessee \\ and \\ Department of Geological Sciences \\ University of Tennessee \\ Knoxville, Tennessee
}

Prepared for

U.S. Department of Energy

Office of Environmental Restoration and Waste Management under budget and reporting codes CD 1072 and EW 20

Oak Ridge K-25 Site

Oak Ridge, Tennessee 37831-7101

managed by

MARTIN MARIETTA ENERGY SYSTEMS, INC.

for the

U.S. DEPARTMENT OF ENERGY

under contract DE-AC05-84OR21400 


\section{DISCLAIMER}

This report was prepared as an account of work sponsored by an agency of the United States Government. Neither the United States Goverament nor any agency thereof, nor any of their employees, makes any warranty, express or implied, or assumes any legal liability or responsibility for the accuracy, completeness, or usefulness of any information, apparatus, product, or process disclosed, or represents that its use would not infringe privately owned rights. Reference herein to any specific commercial product, process, or service by trade name, trademark, manufacturer, or otherwise does not necessarily constitute or imply its endorsement, recommendation, or favoring by the United States Government or any agency thereof. The views and opinions of authors expressed herein do not necessarily state or reflect those of the United States Government or any agency thereof. 


\section{DISCLAIMER}

Portions of this document may be illegible electronic image products. Images are produced from the best available original document. 


\section{CONTENTS}

EXECUTIVE SUMMARY $\ldots \ldots \ldots \ldots \ldots \ldots \ldots \ldots \ldots \ldots \ldots \ldots$ vii

1. INTRODUCTION $\ldots \ldots \ldots \ldots \ldots \ldots \ldots \ldots \ldots \ldots \ldots \ldots \ldots \ldots$

2. GEOLOGIC SETTING AND PREVIOUS WORK $\ldots \ldots \ldots \ldots \ldots \ldots \ldots$

3. DESCRIPTIONS OF STRATIGRAPHIC UNITS $\ldots \ldots \ldots \ldots \ldots \ldots \ldots \ldots \ldots$

3.1 ROME FORMATION $\ldots \ldots \ldots \ldots \ldots \ldots \ldots \ldots \ldots \ldots \ldots \ldots$

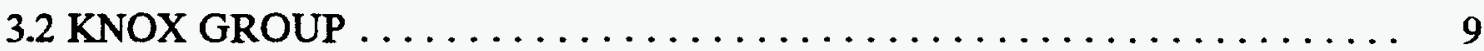

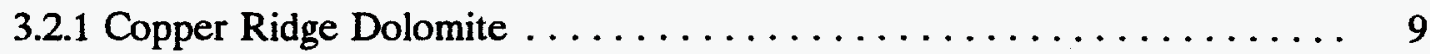

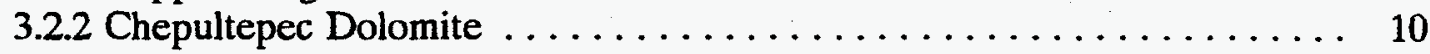

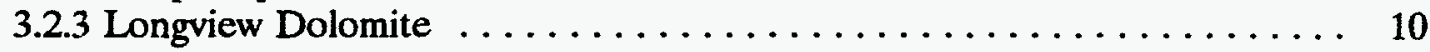

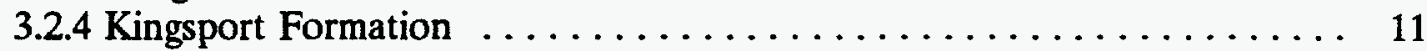

3.2 .5 Mascot Dolomite . . . . . . . . . . . . . . . . . . . . . 11

3.3 CHICKAMAUGA SUPERGROUP-STONES RIVER

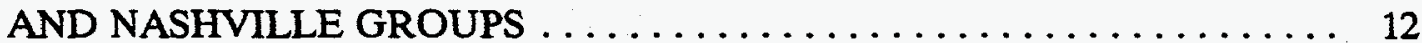

3.3.1 Stones River Group-Pond Spring Formation . . . . . . . . . . . 12

3.3.2 Stones River Group-Murfreesboro Limestone . . . . . . . . . . . . 13

3.3.3 Stones River Group-Ridley Limestone . . . . . . . . . . . . . . . . 13

3.3.4 Stones River Group-Lebanon Limestone . . . . . . . . . . . . 13

3.3.5 Stones River Group-Carters Limestone . . . . . . . . . . . . 14

3.3.6 Nashville Group-Hermitage Formation . . . . . . . . . . . . 15

3.3.7 Nashville Group-Cannon Limestone . . . . . . . . . . . . 15

3.3.8 Nashville Group-Catheys Formation . . . . . . . . . . . . 15

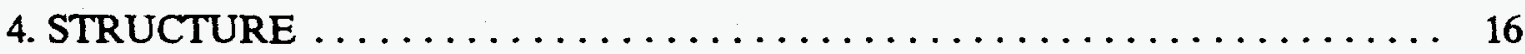

4.1 MAP-SCALE STRUCTURES $\ldots \ldots \ldots \ldots \ldots \ldots \ldots \ldots \ldots \ldots \ldots \ldots \ldots$

4.2 BEDROCK FRACTURE SYSTEM $\ldots \ldots \ldots \ldots \ldots \ldots \ldots \ldots \ldots \ldots$

5. KARST LANDFORMS, SEEPS, AND SPRINGS $\ldots \ldots \ldots \ldots \ldots \ldots \ldots \ldots$

6. SUMMARY AND SUGGESTIONS FOR FUTURE WORK $\ldots \ldots \ldots \ldots \ldots \ldots$

6.1 BEDROCK CORE DRILLING AND GEOPHYSICAL WELL LOGGING . . 30

6.2 OUTCROP STRUCTURAL ANALYSIS $\ldots \ldots \ldots \ldots \ldots \ldots \ldots \ldots \ldots \ldots$

6.3 OUTCROP STRATIGRAPHIC ANALYSIS $\ldots \ldots \ldots \ldots \ldots \ldots \ldots \ldots \ldots \ldots$

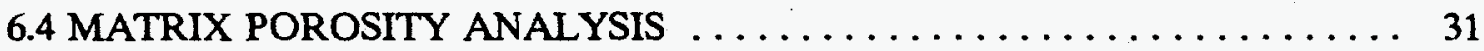

6.5 GEOLOGY AND KARST DEVELOPMENT $\ldots \ldots \ldots \ldots \ldots \ldots \ldots \ldots \ldots$

REFERENCES $\ldots \ldots \ldots \ldots \ldots \ldots \ldots \ldots \ldots \ldots \ldots \ldots \ldots \ldots \ldots \ldots \ldots \ldots \ldots \ldots \ldots$

Appendix A. STRATIGRAPHIC AND STRUCTURAL DATA $\ldots \ldots \ldots \ldots \ldots$

Appendix B. GEOLOGIC MAP OF THE OAK RIDGE K-25 SITE AREA $\ldots \ldots \ldots 47$ 


\section{FIGURES}

1. Location of the Oak Ridge Reservation in the southern Appalachian foreland

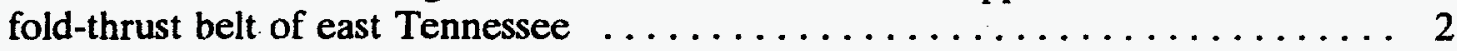

2. Geologic map of the Oak Ridge Reservation ................. 4

3. Balanced cross section from the undeformed foreland of the Cumberland Plateau province through the Oak Ridge area to the Beaver Valley fault in the Valley and

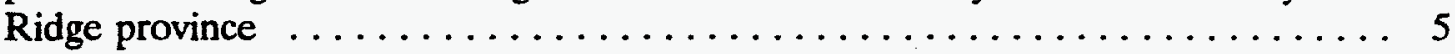

4. Bedrock geologic map of the K-25 Site area $\ldots \ldots \ldots \ldots \ldots \ldots \ldots \ldots \ldots$

5. Stratigraphic section of rock units in the K-25 Site area $\ldots \ldots \ldots \ldots \ldots \ldots 8$

6. Geology along the Whiteoak Mountain fault in the Oak Ridge area $\ldots \ldots \ldots \quad 17$

7. Bedrock geologic map of the K-25 Site area with locations of cross sections . . . 19

8. Geological cross sections across the K-25 Site area $\ldots \ldots \ldots \ldots \ldots \ldots \ldots$

9. Map of mesoscopic faults and folds $\ldots \ldots \ldots \ldots \ldots \ldots \ldots \ldots \ldots \ldots, 21$

10. Map of fracture set strikes measured in outcrops across the K-25 Site area . ... 24

11. Fracture data plots for the K-25 Site area $\ldots \ldots \ldots \ldots \ldots \ldots \ldots \ldots 25$

12. Sketch from a photograph of an outcrop in the Murfreesboro Limestone . . . . 27

13. Map of karst landforms, seeps, and springs area encountered during geological

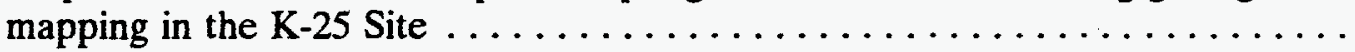




\section{EXECUTIVE SUMMARY}

The Oak Ridge K-25 Site (formerly known as the Oak Ridge Gaseous Diffusion Plant) is located in the southern Appalachian Valley and Ridge province of east Tennessee and overlies an area of folded and faulted Cambrian through Ordovician sedimentary rocks in the footwall of the Whiteoak Mountain fault. Environmental restoration plans for the area require that the geology of the site be well understood because various aspects of the groundwater system are directly influenced by stratigraphic and structural characteristics of the bedrock. This study involved mapping the bedrock geology of an 18-square mile area in and around the plant site. Field mapping focused on: (1) checking the accuracy of previously mapped stratigraphic and fault contacts, (2) dividing the bedrock into distinct stratigraphic units based on field criteria, (3) determining the geometry of map-scale folds and faults, and (4) documenting various aspects of the local fracture system.

Besides accomplishing all of the above tasks, results from this study have led to a number of new hypotheses regarding various aspects of the site geology. First, faulting and folding within carbonates of the Chickamauga Supergroup in the plant area has repeated certain rock units, which requires that there be a thrust fault in the subsurface below them. This thrust fault may project to the surface with the Carters Limestone. Second, thrust slices of the Rome Formation that overlie the Chickamauga carbonates may be extremely thin and have a limited aerial extent. Third, part of the Knox Group on McKinney Ridge is folded into an anticline. Evaluating the above hypotheses will require information about the subsurface that can only be acquired through drilling and surface geophysical surveys. The geologic map produced from this study can be used to evaluate the location of coreholes that will more effectively intersect a combination of stratigraphic, structural, and hydrologic targets. 


\section{INTRODUCTION}

The Oak Ridge K-25 Site (formerly known as the Oak Ridge Gaseous Diffusion Plant) was constructed in the 1940s and was used for the enrichment of $\mathrm{UF}_{6}$ until 1985. As a result of activities at the site, nonhazardous, hazardous, radioactive, and mixed wastes have been stored, treated, and disposed of at various locations (Poling et al. 1992). The site is located in the southern Appalachian Valley and Ridge province and overlies an area of folded and faulted Paleozoic sedimentary rocks (Fig. 1). The complex geology of the site needs to be well defined because various aspects of the groundwater system are directly influenced by stratigraphic and structural characteristics of the bedrock. For example, underlying the site is a sequence of carbonate and noncarbonate sedimentary rock types. Throughout the area, carbonate rock units have developed a karst groundwater system, and noncarbonate rocks have groundwater flow through fractures (Solomon et al. 1992). Because groundwater flow rates in karst conduits are faster than in fractures, it is important to determine the location and characteristics of karstified carbonate rock units and the geologic factors that control their development.

The purpose of this study was to produce a 1:12,000-scale bedrock geologic map of the K-25 Site and surrounding area. Field mapping covered $\sim 18$ square miles and was completed during the winter and spring of 1992-1993. Stratigraphic and structural data were recorded from over 250 outcrops and are included in Appendix A. The geologic map of the K-25 Site area generated by this study is included as Appendix B. Field mapping focused on: (1) checking the accuracy of previously mapped stratigraphic and fault contacts; (2) dividing the bedrock into distinct stratigraphic units based on field criteria; (3) determining the geometry of map-scale folds and faults; and (4) characterizing various aspects of the local fracture system. Furthermore, since most of the area is underlain by carbonate rock, various karst landforms and features were mapped, including: seeps and springs, sinkholes, a sinking stream, pinnacles, and open cavities. The results from this study will be used as a framework in which to interpret old bedrock well logs and groundwater data. The results will also be used as the groundwork for developing a drilling strategy to investigate the geologic factors that control the development of groundwater flow pathways. 


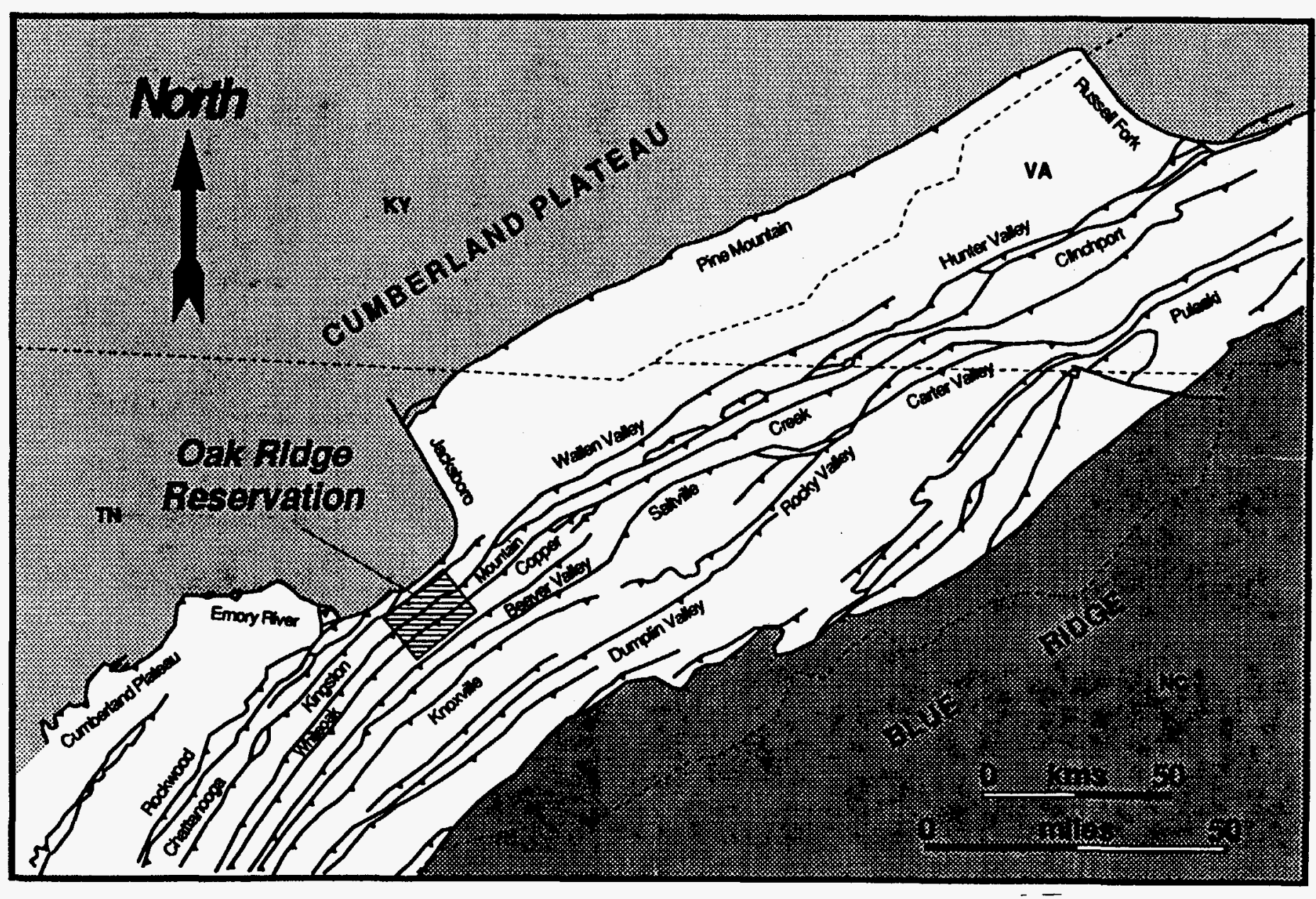

Fig. 1. Location of the Oak Ridge Reservation in the southern Appalachian foreland fold-thrust belt of east Tennessee. 


\section{GEOLOGIC SETTING AND PREVIOUS WORK}

The Oak Ridge Reservation (ORR) is located in the western portion of the Appalachian Valley and Ridge physiographic province in east Tennessee. The Valley and Ridge topography is related to the differential resistance to erosion of folded and thrust-faulted Cambrian through Pennsylvanian sedimentary rocks (Fenneman 1938). The deformational event that caused the development of the southern Appalachian fold-thrust belt was the Late Paleozoic Alleghanian orogeny (Hatcher 1987). The three regional thrust faults that are responsible for the bedrock structures present on the ORR are the Copper Creek, Whiteoak Mountain (WM), and Kingston faults (Fig. 2). These faults strike northeast, dip southeast, and cause the Paleozoic stratigraphic units to be repeated three times (Fig. 3). See Hatcher et al. (1992) for a detailed discussion of the geology of the ORR.

The K-25 Site area is located on the trailing edge of the Kingston thrust sheet, adjacent to the WM fault (Hardeman 1966). Bedrock structure in the area is closely related to the development of the East Fork Ridge syncline and WM fault. The major stratigraphic units involved in the deformation are the Rome Formation, underlying Pine Ridge and parts of the valley to the northwest; the Knox Group, underlying Blackoak Ridge and McKinney Ridge; and the Chickamauga Supergroup, which underlies the low-lying areas between the foregoing ridges. The Conasauga Group underlies Sugar Grove Valley to the northwest and Bear Creek Valley to the southeast of the plant area. Neither shales nor carbonates of the Conasauga Group were found exposed in the plant area, but it is possible that fault slices may exist at depth.

The interpretation of the bedrock geology in the K-25 Site area has changed little since the early work of Rodgers (1953). Reconnaissance field maps by McMaster (1962) and later by R. H. Ketelle (personal communication 1992), however, better defined the location of the major stratigraphic contacts and hinted at the complex bedrock structures in the area (Fig. 4). The geology southwest of the Clinch River between Blackoak Ridge and Pine Ridge was mapped by Jones (1963), and Ossi (1979) mapped part of the Chickamauga Supergroup during construction of the proposed Synfuels site. More recent hydrogeologic studies have proposed slight changes to the site geologic map (e.g., Geraghty \& Miller 1989). The changes involved (1) having a continuous section from the Knox Group on the south side of McKinney Ridge down to the upper part of the Conasauga Group under Blair Road; and (2) having a portion of the Shady Dolomite underlying the Rome Formation in the WM thrust sheet. Although present mapping covered these areas, the validity of these changes could not be confirmed because of the lack of bedrock exposure. The present map does not include these new interpretations because the available reports do not convincingly document them. 


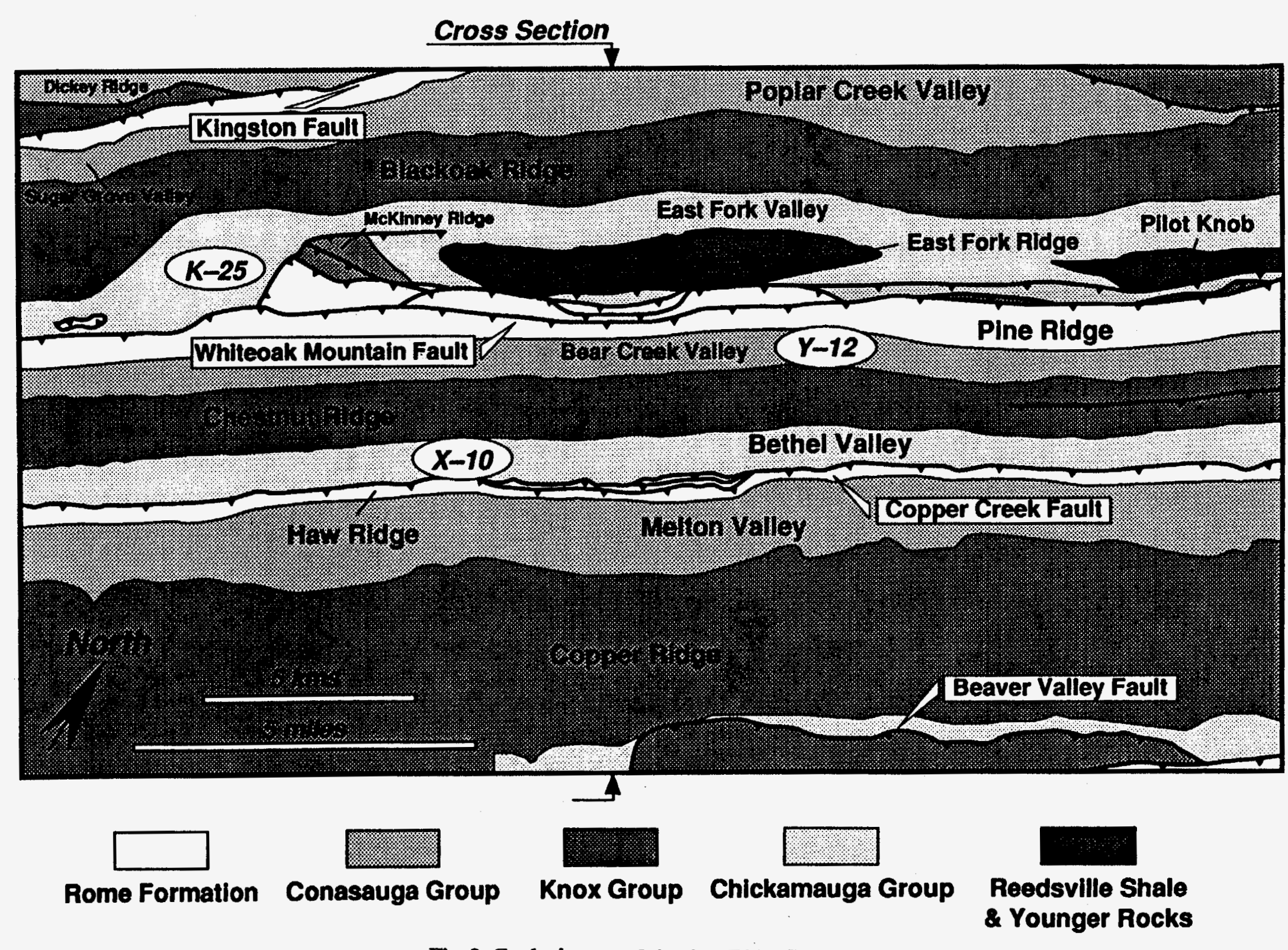

$\rightarrow$

Fig. 2. Geologic map of the Oak Ridge Reservation. 

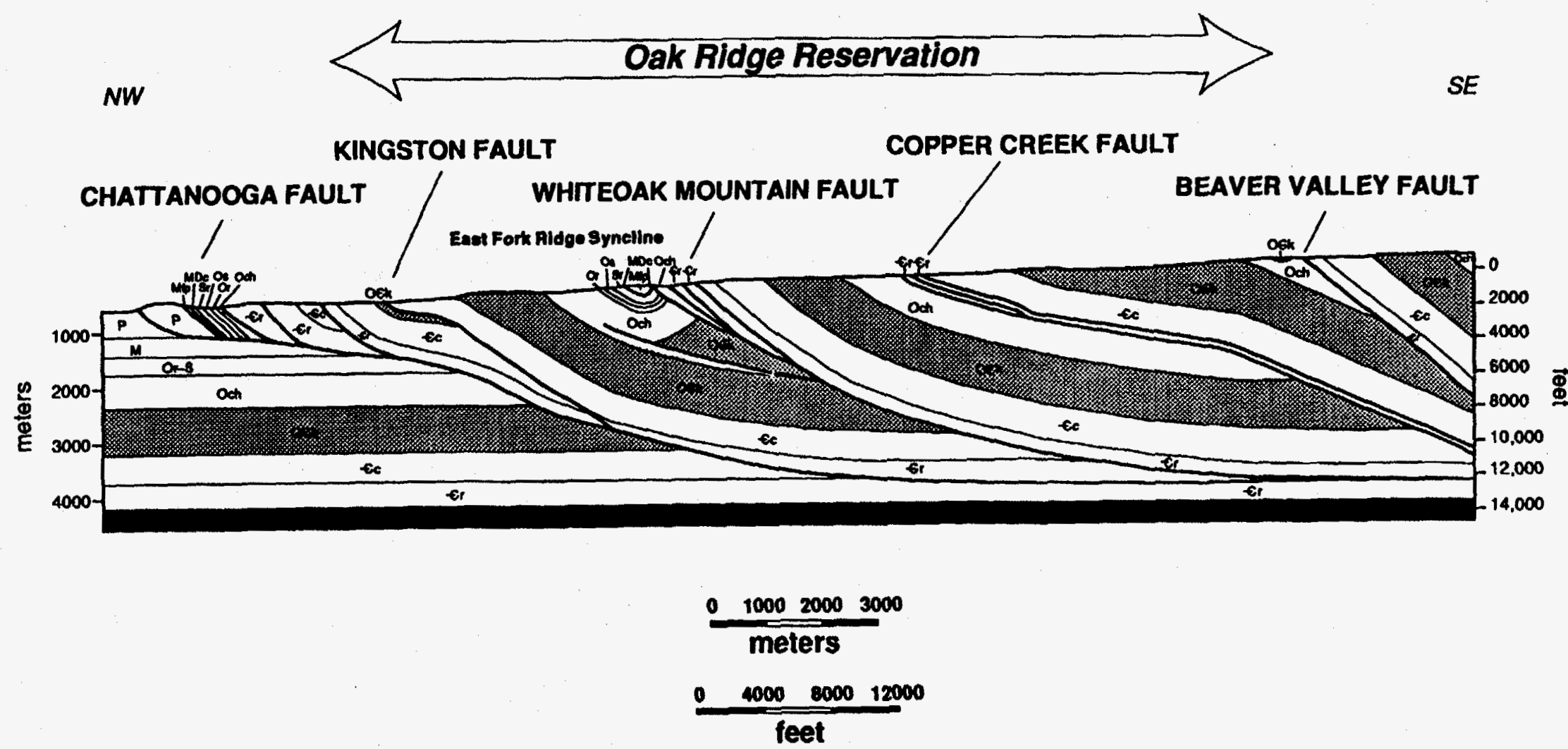

Fig. 3. Balanced cross section from the undeformed foreland of the Cumberland Plateau province through the Oak Ridge area to the Beaver Valley fault in the Valley and Ridge province. $P=$ Pennsylvanian; $M=$ Mississippian; $S=$ Silurian; Or = Reedsville Shale; Os = Sequatchie Formation; $\mathrm{Sr}=$ Rockwood Formation; $\mathrm{MDc}=$ Chattanooga Shale; $\mathrm{Mfp}=$ Fort Payne Formation. See Fig. 5 for explanation of other stratigraphic formation symbols. 

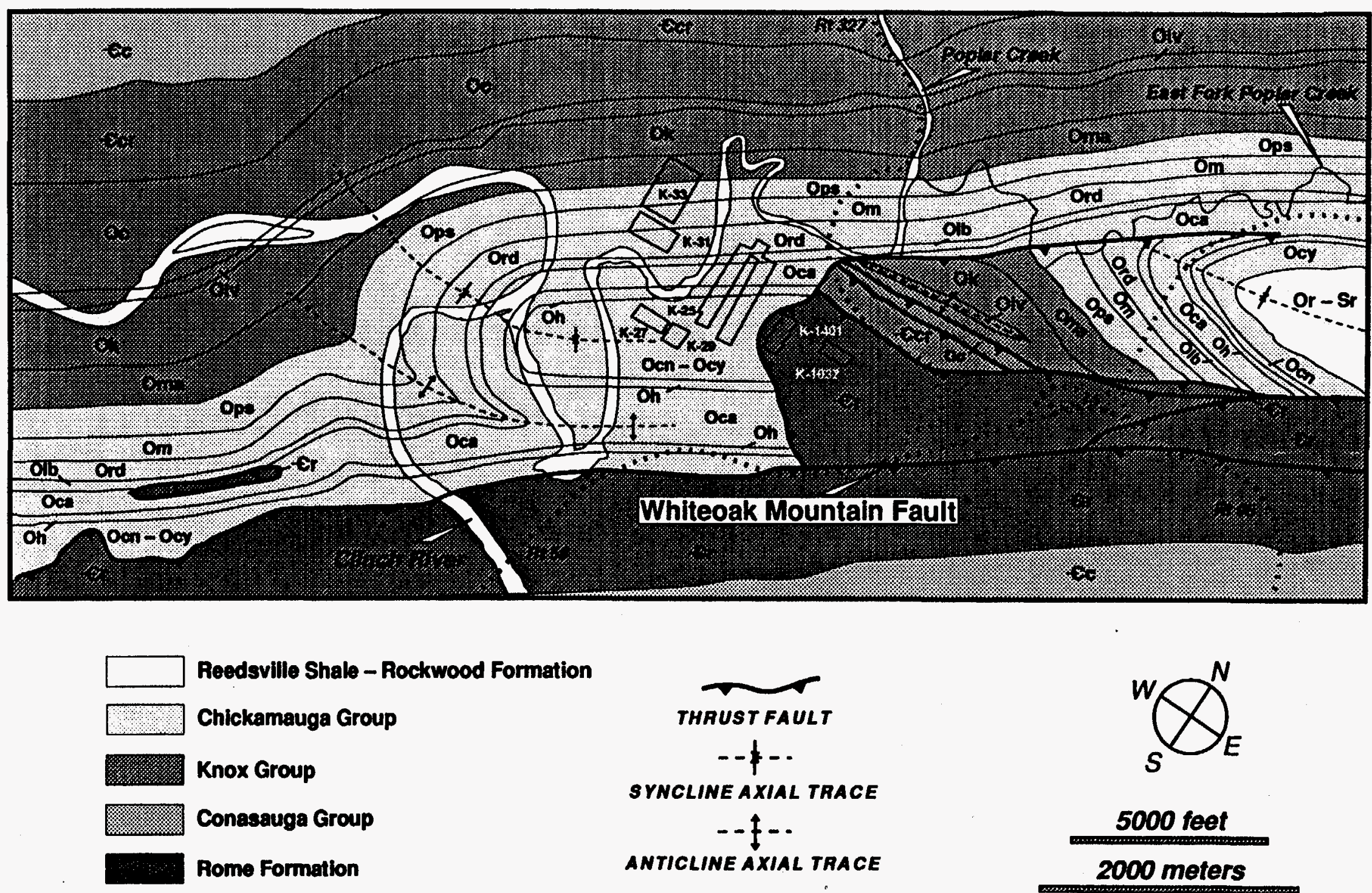

Fig. 4. Bedrock geologic map of the $\bar{K}-25$ Site area. See Fig. 5 for key to stratigraphic unitit symbois. 


\section{DESCRIPTIONS OF STRATIGRAPHIC UNITS}

The bedrock stratigraphic units on the ORR and vicinity range in age from Early Cambrian to the Early Mississippian (Fig. 5). The sedimentary deposits record the evolution of the southern Appalachian basin from a passive margin to a foredeep basin during the lower Paleozoic, and ultimately to a foreland basin for the remainder of Paleozoic time (Rankin et al. 1989). The Rome Formation, Knox Group, and Chickamauga Supergroup are present in the K-25 Site area. Parts of the Conasauga Group may occur in thrust slices on the south side of McKinney Ridge, but no exposures were found, and therefore the unit is not described below. See Hatcher et al. (1992) for a discussion of the geology of the Conasauga Group on the ORR.

Every effort was made to correlate rock units based on criteria previously used throughout the rest of the ORR, as well as to correlate distinctive lithologic intervals within each rock unit. Exposures of the Rome Formation are rare and commonly deformed, which precluded efforts to correlate specific stratigraphic intervals. The Knox Group was divided into five formations by using characteristic chert and sandstone lithologies. These marker units have been found elsewhere on the reservation and were previously mapped towards the northeast on Blackoak Ridge, near the city of Oak Ridge (Hatcher et al. 1992). In the K-25 Site area, division of the Chickamauga Supergroup into seven formations was accomplished by using lithologic criteria originally recognized in middle Tennessee (Wilson 1949) that was later extended to Georgia and the Sequatchie Valley in east Tennessee (Milici and Smith 1969). These criteria have been used with slight modifications to divide the Chickamauga Supergroup, northeast of the K-25 Site area in East Fork Valley (Hatcher et al. 1992).

\subsection{ROME FORMATION}

The Rome Formation is the oldest rock unit exposed in the area and was named by Hayes (1891) for exposures at Rome, Floyd County, Georgia. The unit underlies Pine Ridge and parts of the valley and hilly topography to the northwest. Sandstones in the upper Rome are the ridge formers and shales in the lower Rome floor the valley. The lower contact of the Rome Formation is the WM fault. Displacement along the WM fault is responsible for transporting the Rome to its present location and leaving behind the lower contact with the Lower Cambrian Shady Dolomite. Because the lower contact has not been found anywhere in east Tennessee, and because the unit has been internally thickened and thinned by mesoscopic folding and faulting, the true thickness of the Rome Formation is poorly constrained. The upper contact of the Rome Formation is located on the southeast side of Pine Ridge and is placed at the top of the last prominent sandstone bed below characteristic shales and siltstones of the Pumpkin Valley Shale. Sedimentological studies of the Rome Formation conclude that it was deposited in a peritidal environment on the Early Paleozoic North American passive margin (Spigai 1963, Samman 1975, McReynolds 1988). 


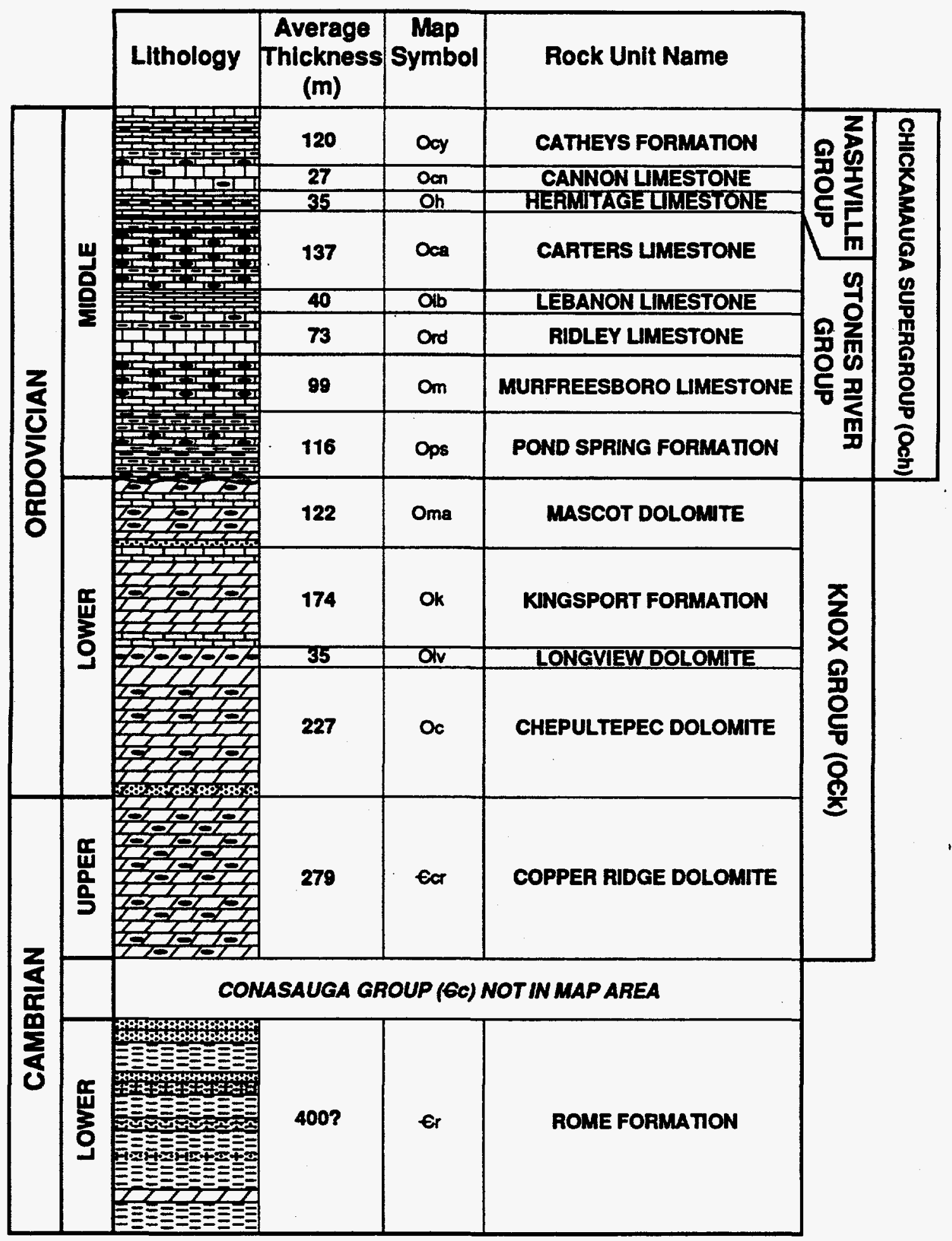

Fig. 5. Stratigraphic section of rock units in the K-25 Site area. 
Exposures of the lower part of the Rome Formation in the WM thrust sheet are sparse, and therefore a complete description of the unit cannot be made. Most exposures contain thin-bedded shale and siltstone with abundant mica flakes. These lithologies have the characteristic variegated maroon, green, and yellow-brown colors and may represent the Apison Shale Member of the Rome Formation (Hayes 1894, Wilson 1986). Thin-bedded maroon, brown, and gray sandstones are also present. A few small exposures of a weathered carbonate have been found in the lower Rome shales, but not enough to trace across the map area. Towards the northeast, an apparently more extensive carbonate unit has been mapped in the Rome and was considered the contact between the lower and upper parts (Beets 1985). The unit weathers into soil containing shale and siltstone chips and small sandstone blocks. Fragments of bluish-white, tan-brown, and chalcedonic chert are derived from carbonate beds.

The upper Rome Formation consists predominantly of maroon sandstone, siltstone, and shale. Shales in the upper Rome are thin bedded and come in a variety of colors, such as olive-green, light brown, green-gray, and maroon. Greenish-gray, yellowish-gray, light-brown, and olive-gray siltstones and sandstones are interbedded with maroon sandstones. The sandstones are silica and hematite cemented, mostly fine- to medium-grained, quartzose and occasionally glauconitic. Ripple bedforms, small-scale crossbedding, flaser bedding, bioturbation, and mud cracks are common sedimentary structures. The erosional resistance of the sandstones is responsible for the development of Pine Ridge. The same sandstone weathering blocks that occur on the crest of Pine Ridge are found on the top of the hills located on the north side of Grid D5. (See Appendix B.) This observation suggests that the WM fault is located in the valley between them and has repeated the upper Rome section.

\subsection{KNOX GROUP}

The Knox Group is a major carbonate sequence that is the only designated aquifer on the ORR (Solomon et al. 1992). The Knox Group has been divided into five formations based primarily on the characteristics of chert and sandstone blocks preserved in the residuum. The thickness of the Knox Group ranges from 800 to $1000 \mathrm{~m}$. The Knox Group was deposited in a peritidal environment on the Late Cambrian-Early Ordovician North American passive margin (Harris 1973, Rankin et al. 1989).

\subsubsection{Copper Ridge Dolomite}

The Upper Cambrian Copper Ridge Dolomite was named for exposures on Copper Ridge in northeast Tennessee and southwest Virginia (Ulrich 1911) and is $-280 \mathrm{~m}$ thick.

The lower part of the Copper Ridge is characterized by dark gray and brown, massivelybedded, medium-to-coarse crystalline dolomite. Saccharoidal (sugary) texture is a common feature that consists of large, nearly equidimensional crystals of dolomite. Freshly broken pieces commonly yield a strong petroliferous odor, which is probably the most distinctive feature of the lower dark gray dolomites. Massive beds in the lower part weather to rough, pitted, irregular surfaces that can obscure bedding. Light-gray, medium crystalline dolomite, typical of the upper part of the Copper Ridge, is interbedded throughout the lower part.

Beds and zones of dolomitized oolite are common in the lower part, but the ooids are difficult to identify in unweathered rock. Oolitic beds that have been replaced by chert, 
however, are very distinctive. Most silicified ooids are spherical, but oval or tabular shapes were also observed. Some silicified ooids have concentric color bands, whereas others are of uniform color throughout but show an onion-like structure. The ooids are gray or white and occur in a matrix of white chert. Cobbles of oolitic chert are abundant in soil derived from the Copper Ridge Dolomite, as well as another variety of white and gray chert with internal laminations, probably inherited from original depositional structures. In addition, dark gray, cryptozoon (algal) chert is common in float and was the only fossil found in the unit. The lower part usually produces a deep-red soil but may also produce a light-tan soil where cherty.

The upper part of the Copper Ridge Dolomite consists primarily of light-gray dolomite that tends to occur as more evenly stratified medium to thick beds. The dolomite varies from fine- to coarse-grained. Interbedded with the dolomite are the dark gray dolomite beds with a petroliferous odor that are characteristic of the lower part. Chert is very common in the upper part and has similar characteristics as the chert in the lower part. In particular, a coarse-grained, white and gray, oolitic chert bed occurs slightly below the upper contact. Scattered sandstone lenses and dolomite with quartz grains are present in the upper part but are not as abundant as in the overlying Chepultepec Dolomite.

\subsubsection{Chepultepec Dolomite}

The Lower Ordovician Chepultepec Dolomite conformably overlies the Copper Ridge Dolomite and is $-230 \mathrm{~m}$ thick. The Chepultepec Dolomite was named for exposures near Chepultepec, Blount County, Alabama (Ulrich 1911). The unit commonly forms a valley between ridges underlain by the more siliceous Copper Ridge Dolomite and Longview Dolomite. Exposures of the Chepultepec are rare, but chert float is conspicuous and distinctive. The lower contact with the Copper Ridge Dolomite is marked by a change from a red clay soil with gray oolitic chert blocks to an orange sandy soil with either silica-cemented or dolomite cemented sandstone blocks and white oolitic chert blocks. The contact with the overlying Longview Dolomite is determined based on the presence of large float blocks of white, porcelaneous chert. Weathering of the main body of the Chepultepec Dolomite produces orange to red clay soil that contains sandy streaks and scattered masses of oolitic chert with white to light-gray centers and rims.

The Chepultepec consists of fine to medium-grained dolomite that is commonly mediumto thick-bedded and light-gray or tan colored. Although other types of dolomite are present, they are less abundant than the light-colored varieties. Oolitic chert in the Chepultepec is generally a lighter color than in the Copper Ridge Dolomite. Much of the chert found in float is light gray, cream, tan, and white. The chert is commonly deeply weathered with black stains and contains rhombohedral shaped molds of weathered dolomite crystals.

\subsection{Longview Dolomite}

The Lower Ordovician Longview Dolomite was named by Butts (1926) for exposures near the town of Longview, Shelby County, Alabama. The Lower Ordovician Longview Dolomite commonly forms a prominent narrow ridge near the center of the broad ridge developed by the Knox Group. The Longview is $-35 \mathrm{~m}$ thick.

The Longview is composed of interbedded light- to medium-gray, thin- to thick-bedded, fine- to coarse-grained dolomite. The dolomite commonly contains light-gray to white, 
concentrically banded chert nodules, lenses, and large masses. Weathering of the Longview Dolomite produces a clay soil that contains abundant blocks of massive, milky white, chalcedonic chert that are occasionally dolomoldic and oolitic. In addition, nodules of black, red, blue, and tan chert occur.

\subsection{Kingsport Formation}

The Lower Ordovician Kingsport Formation is $\sim 175 \mathrm{~m}$ thick. On a map of the Copper Ridge zinc district, Rodgers (1943) named the Kingsport Formation for the city of Kingsport, Sullivan County, Tennessee. In general, less chert is produced from weathering of the Kingsport than the other formations of the Knox Group. The Kingsport usually underlies gentle slopes or valleys located downdip from ridges developed by the Longview Dolomite. The contact with the Longview Dolomite is marked where jasperoidal chert diminishes in float and milky white chert becomes more abundant.

Dolomites in the Kingsport Formation range from light to dark gray, medium- to massively-bedded, and fine to coarsely crystalline. Some dolomites have an oolitic texture. Near the top of the formation the gray color of the dolomite may contain pink streaks or have a pinkish hue. Thick to massive limestones are commonly interbedded with the dolomites. The limestones are light to medium gray and fine-grained, with various forms of chert. Jasperoidal chert is fairly common in the unit and ranges from irregular pods and lenses to well-defined thick beds. The jasperoidal chert can be fine-grained crystalline and may have a sandy texture. Gastropods have been found in various varieties of chert throughout the unit but are found mostly in milky-white-colored cherts near the contact with the overlying Mascot Dolomite.

\subsubsection{Mascot Dolomite}

The Lower Ordovician Mascot Dolomite was named by Rodgers (1943) on a map of the Copper Ridge zinc district, but the type area of the unit is the Mascot-Jefferson City zinc district, northeast of Knoxville, Tennessee. The Mascot Dolomite has the greatest range in thickness because the top of the unit is an unconformity. The unconformity represents erosion of the Mascot prior to deposition of the overlying carbonate sequence. The basal contact of the Mascot with the Kingsport Formation consists of thick-bedded dolomites that contain a zone of jasperoidal, chert matrix sandstone. In the K-25 Site area the average thickness of the Mascot Dolomite is $122 \mathrm{~m}$.

The Mascot is primarily composed of thick- to massively-bedded light-gray dolomite with pinkish streaks and hues. The dolomite is commonly fine grained, but occasional thick beds of coarse-grained dolomite with scattered quartz sand grains also occur in the unit. Rare limestone beds in the unit are thick to massive, light gray, and fine grained. Limestones contain some silicified gastropods, irregular dolomitic patches, and black chert pods. Near the base of the unit is a jasperoidal and flinty chert zone that commonly has cabbage-head-shaped stromatolitic (algal) laminations. Near the middle of the unit is a medium- to thick-bedded white porcelaneous chert. Both of these chert layers were easily traced in the residuum. 


\subsection{CHICKAMAUGA SUPERGROUP-STONES RIVER AND NASHVILLE GROUPS}

The entire Middle and Upper Ordovician carbonate sequence is preserved in the Kingston thrust sheet and is $\sim 575 \mathrm{~m}$ thick. Previous work in the area divided the Ordovician Chickamauga Supergroup based on lithologic characteristics (McMaster 1957, Kemp 1954, Borowski 1982), but no formal stratigraphic nomenclature was prescribed to the mapped units. These studies, however, did locate some of the distinctive features that are characteristic of particular formations mapped elsewhere in Tennessee. For example, Borowski (1982) described the metabentonites, which are characteristic of the Carters Formation. Ghazizadeh (1987) applied middle Tennessee formation names to four Chickamauga sections southwest of the K-25 Site. Ghazizadeh, however, did not describe the criteria that distinguish each formation, and, more importantly, his section descriptions do not identify some of the primary marker beds, such as the metabentonites, that are needed to identify particular units properly. Milici (1991, personal communication) mapped the Chickamauga in the Kingston thrust sheet along the shoreface of the Watts Bar Reservoir and was able to use middle Tennessee stratigraphic characteristics and marker beds to identify the formations of the Stones River and Nashville Groups. Similar field criteria as Milici's were successfully used to identify and divide the Chickamauga Supergroup in East Fork Valley to the northeast of the K-25 Site (Hatcher et al. 1992). Lithofacies analysis indicates that the carbonate sequence represents a tidal flat and subtidal-lagoonal environment on a gently sloping platform (Ghazizadeh 1987).

\subsubsection{Stones River Group-Pond Spring Formation}

The Pond Spring Formation was named by Milici and Smith (1969) for exposures in northwestern Georgia. The Pond Spring was deposited on the irregular erosion surface of the Knox disconformity and occupies a topographic low between the southeastern side of Blackoak Ridge and a small rise in elevation near the contact with the overlying Murfreesboro Limestone. The Pond Spring is a distinctive mudstone-rich formation at the base of the Chickamauga Supergroup and should be an excellent unit for subsurface correlations in this part of the stratigraphic section. The thickness of the Pond Spring is fairly constant across. the map area, at $\sim 120 \mathrm{~m}$.

Basal exposures of the Pond Spring have been reported to range from a conglomerate of light-greenish-red, fine-grained dolomite, to thin- to medium-bedded, light-greenish-gray, fine-grained limestone, to lenses of calcareous shale and sandstone (Borowski 1982, Wilson 1986). The basal contact was exposed along the Clinch River in the K-25 Site area and consisted of calcareous shales and argillaceous limestone overlying thick-bedded dolomite of the Mascot Dolomite. The lower and upper parts of the formation consist of maroon, green, and gray argillaceous limestone. Bedding ranges from thin to medium, even, regular beds to mottled, uneven beds. Interbedded with the limestones are thick, irregularly-bedded, calcareous shales that are grayish-green and red. Within the middle part of the Pond Spring is a thick- to massive-bedded, dark-gray, micritic limestone with bed-parallel gray chert pods. Although the position of this unit in the Pond Spring may vary slightly across the map area, it is a fairly distinctive unit that may be a useful marker bed for correlating the upper and lower parts of the Pond Spring. Fossils are very rare, but a few silicified gastropods have been found. 


\subsubsection{Stones River Group-Murfreesboro Limestone}

The Murfreesboro Limestone was named by Safford and Killebrew (1900) for exposures in and around Murfreesboro, Rutherford County, Tennessee. The Murfreesboro Limestone contact with the Pond Springs Formation is placed where argillaceous limestone and mudstone are overlain by thin- to thick-bedded, micrite and fine-grained crystalline limestone. The unit averages $100 \mathrm{~m}$ in thickness.

The lower part of the Murfreesboro consists primarily of micritic and fine-grained crystalline limestone. The limestones are usually thin bedded, although very thick to massive beds do occur in the section. Minor amounts of calcareous shale and argillaceous limestone also exist in the lower part. The middle part of the Murfreesboro consists of similar micritic and fine-grained limestones, but beds are commonly thin to medium, regular, and even. Bryozoans are the only fossils that have been observed in the middle part, and bed-parallel, ropy, black chert zones increase in abundance. Thick to massive beds interbedded with even, thin to medium beds become more common in the upper part of the Murfreesboro, but they are not as abundant as in the overlying Ridley Limestone. A characteristic feature of the limestones in the upper part of the Murfreesboro is that they commonly contain nodular, ropy, gray-black chert zones with silicified fossils.

\subsubsection{Stones River Group-Ridley Limestone}

The Ridley Limestone was named by Safford (1869) for exposures in Rutherford County, Tennessee, and is $\sim 75 \mathrm{~m}$ thick in the map area. The contact with the underlying Murfreesboro Limestone is placed where regularly bedded, chert rich limestones of the Murfreesboro are overlain by thick- to massively-bedded, fucoidal limestones that contain little to no chert.

Thick- to massively-bedded, fucoidal-textured limestone is characteristic of the Ridley Limestone. "Fucoidal texture" is a term used to describe the presence of tan-brown, irregularly shaped, fine- to coarse-grained dolomitic patches within the limestone. The texture appears to be related to the preferred dolomitization of a preexisting mottling fabric. The limestones are generally dark-gray micrite that are commonly devoid of fossils. Within the middle part of the Ridley is a yellowish-red, mud-cracked, calcareous shale. The unit is fairly distinctive, but because of poor exposure, the thickness of this unit is not known, and it is not known whether the unit can be used as a marker for subsurface correlations. Within the upper part of the Ridley Limestone, minor amounts of gray-black chert are present, and fossils are very abundant in some coarse-grained limestone beds.

\subsubsection{Stones River Group-Lebanon Limestone}

The Lebanon Limestone was named by Safford and Killebrew (1900) for exposures near Lebanon, Wilson County, Tennessee. The Lebanon Limestone is $\sim 40 \mathrm{~m}$ thick in the map area. The contact with the Ridley Limestone is placed where thick to massive beds of limestone are overlain by thin, cobbly-bedded, fucoidal, very fossiliferous limestone.

A distinctive characteristic of the Lebanon Limestone is the abundance of fossils. Wholebody and disarticulated brachiopods, bryozoans, gastropods, and cephelopods have been observed. Bedding in the Lebanon ranges from regular and even, thin to medium beds, to 
irregular, cobbly beds. Cobbles are more pronounced after the beds have been extensively weathered and are elongate, micritic- to coarse-grained limestone lenses, parallel to bedding, that are surrounded by thin laminae of calcareous mud. Some thick to massive limestone beds also occur in the Lebanon. Fucoidal texture is common. Chert is rare.

\subsubsection{Stones River Group-Carters Limestone}

The Carters Limestone was named by Safford (1869) for exposures along Carters Creek in Maury County, Tennessee. The Carters Limestone is $\sim 150 \mathrm{~m}$ thick in the study area. The contact with the Lebanon Limestone was not exposed in the study area but is located between outcrops of thin-bedded, fossiliferous limestones of the Lebanon and thick-bedded limestones with few fossils of the Carters.

The lower part of the Carters Limestone consists of thick to massive beds of interbedded micritic- and coarse-grained limestone. Chert in the lower part consists of gray-black pods and lenses. Where outcrops are absent, chert blocks are relatively abundant in the residuum. The top of the lower part consists of olive-gray, argillaceous limestone that is mud-cracked and devoid of fossils and weathers into thin chips.

The middle part of the Carters Limestone consists of medium to thick, regular- and evenbedded, blue-gray limestone. Close examination of the beds indicates that some are storm deposits consisting of fining upward sequences of coarse-grained fossil hash to micrite. Fossil hash beds commonly have Tetradium coral. Fucoidal texture and gray chert pods are also common. Although no exposures were found, a quartz siltstone has commonly been observed in float around the middle part of the Carters. At the top of the middle part are two applegreen, sometimes partly maroon, metabentonite beds that range from 1 to $3 \mathrm{ft}$ in thickness. Although exposures of the metabentonites were not found in the area during mapping, they have been observed along strike toward the southwest and northeast. An exposure of the metabentonites, however, was found along Poplar Creek before the K-25 Site was built (Fox and Grant 1944). The metabentonites are characteristic marker beds in the Carters Limestone and have been named T-3 and T-4 by Wilson (1949). The metabentonites range from mudsized to fine-grained and are very micaceous. Relatively large biotite flakes are characteristic of T-4 and can be used to distinguish between the beds when only one unit is found (Milici and Smith 1969). Underlying each metabentonite bed are gray-black cherts that are commonly medium-bedded (table-top cherts) and fossiliferous. Formation of the cherts may be related to burial alteration of the metabentonites, causing silica to be dissolved and reprecipitated in the underlying limestone beds. Soils commonly contain small chert blocks that are fossiliferous and oolitic, as well as pieces of silicified fossils, which helps determine the location of the metabentonites where there are no bedrock exposures. In addition, the cherts are more resistant to weathering, which leads to the development of a small rise in topography that is easily observable on topographic maps. All of the foregoing characteristics have been used to approximate the position of the metabentonites in the map area. The metabentonites will be one of the most useful units for subsurface correlations in this part of the Chickamauga Supergroup.

The upper part of the Carters is poorly exposed but consists of micritic, greenish-gray and yellowish-gray, poorly-bedded, mud-cracked limestone. 


\subsubsection{Nashville Group-Hermitage Formation}

The Hermitage Formation was named by Hayes and Ulrich (1903) for exposures near the Hermitage community in Davidson County, Tennessee. Limestones consists of thin to medium, irregular, uneven, cobbly beds that are abundantly fossiliferous. Fossils are commonly silicified and include crinoids, brachiopods, and bryozoans. Limestones range from light-gray to slightly reddish-gray, coarse-grained spar and micrite that can be partly argillaceous. A maroon, olive-tan, calcareous shale has been observed near the base of the unit and may be a useful marker bed. The Hermitage is $-35 \mathrm{~m}$ thick.

\subsubsection{Nashville Group-Cannon Limestone}

The Cannon Limestone was named by Ulrich (1911) for exposures in Cannon County, Tennessee. A type section was designated by Bassler (1932) in Cannon and Rutherford counties, Tennessee. The Cannon is poorly exposed and may exist only within the minor syncline in the middle of the plant area. The following description is based on exposures mapped along strike to the northeast between the K-25 Site and the city of Oak Ridge. The Cannon Limestone is $\sim 27 \mathrm{~m}$ thick.

Limestones in the Cannon are commonly dark-gray, thick to massive beds, but thin and medium beds also occur. Fossils range from rare to a coquina consisting of crinoids, bryozoans, and brachiopods. A few large silicified coral forms were observed. Chert and fucoidal texture is rare, but stylolites are common and produce ridges on weathered outcrops.

\subsubsection{Nashville Group-Catheys Formation}

The Catheys Formation was named by Hayes and Ulrich (1903) for exposures along Catheys Creek in Lewis and Maury counties, Tennessee. The Catheys is poorly exposed and may exist only within the minor syncline in the middle of the plant area. The following description is based on exposures mapped along strike to the northeast between the K-25 Site and the city of Oak Ridge. The Catheys Formation is $\sim 120 \mathrm{~m}$ thick.

The Catheys Formation is medium to dark-gray, thin- to thick-bedded, micrite and occasionally coarse-grained limestone with shale seams and partings. Some beds are very fossiliferous, and Tetradium have been found. Near the upper part are interbedded calcareous, green and red shales. Chert and siltstone fragments are common in soil. 


\section{STRUCTURE}

\subsection{MAPSCALE STRUCTURES}

The K-25 Site is located on the trailing edge of the Kingston thrust sheet, adjacent to the WM fault (Hardeman 1966). The Kingston fault outcrops to the northwest of the plant area along Dickey Ridge. Based on balanced structural cross sections through the region, the Kingston fault is estimated to be at a depth between 2.5 to $3.0 \mathrm{~km}$ below the plant site and has a minimum displacement of $2 \mathrm{~km}$. The present northeast strike and southeast dip of the Knox Group on Blackoak Ridge and lower parts of the Stones River Group in East Fork Valley was derived from emplacement of the Kingston thrust sheet as it climbed a footwall ramp.

The emplacement of the WM thrust sheet, however, is interpreted to be responsible for the development of the East Fork Ridge syncline and the complex array of structures that underlie the K-25 Site area (Hatcher et al. 1992). The WM fault places a hanging-wall flat in the Rome Formation against a footwall ramp consisting of various stratigraphic units. The footwall ramp geometry in map view is indicated by the presence of footwall synclines, imbricates, and numerous stratigraphic cutoffs against the fault. Evidence for the hanging-wall flat geometry is the lack of stratigraphic cutoffs and the consistent position of the fault in the Rome Formation. A balanced cross section through the area indicates a minimum displacement of $10 \mathrm{~km}$ along the WM fault.

The East Fork Ridge syncline is typical of the structures that have formed on the trailing edge of the Kingston thrust sheet (Rodgers 1953, Hardeman 1966). The development of the syncline is related to the growth of the WM fault. Although only the southwestern portion of the syncline projects into the map area, a brief discussion of the geometry of the entire syncline is given below because various aspects of its geometry are related to structures in the K-25 Site area.

The East Fork Ridge syncline is a prominent topographic feature that involves the folding of Knox Group and younger rock units adjacent to the WM fault (Fig. 6). The syncline has an upright northwest limb and a southeast limb that is overturned to the northwest. Pieces of the southeast limb of the syncline still remain as imbricate slices adjacent to the WM fault, but most of the rock units have been removed by thrusting. The axial plane of the syncline strikes $\mathrm{N} 66 \mathrm{E}$ and dips $84 \mathrm{SE}$, indicating an upright geometry with a slight northwest vergence to the fold. In general, the fold axis (long axis of the fold) is oriented northeast-southwest, parallel to the strike of the WM fault. The geometry of Ordovician and younger rock unit map contacts, however, indicates that the fold axis is doubly plunging. In other words, the fold axis is mildly warped along its trend so that the hinge of the fold projects out of the ground toward the northeast and southwest before rolling over and projecting back into the ground farther along trend. Stereographic projections of poles to bedding from the Rockwood Formation and younger rock units indicate that the northeastern hinge of the syncline has a fold axis with a trend and plunge of S56W / 02SW, and the southwestern hinge of the syncline has a fold axis with a trend and plunge of N66E / $02 \mathrm{NE}$. 


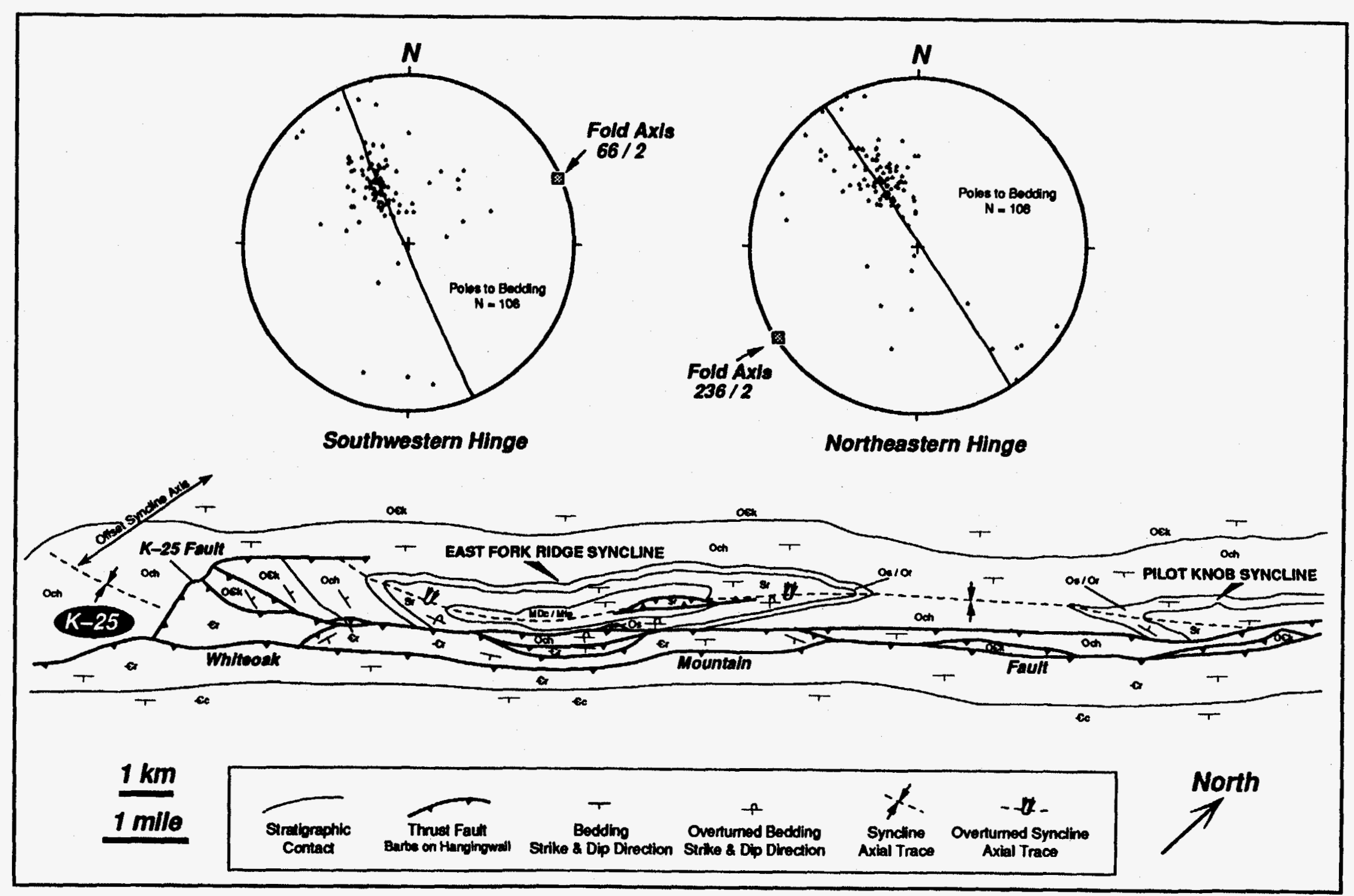

Fig. 6. Geology along the Whiteoak Mountain fault in the Oak Ridge area. Equal area, lower-hemisphere, stereographic projections of poles to bedding around the southwestern and northeastern hinges of the East Fork Ridge syncline. Each syncline hinge was plotted separately to determine the local fold axis orientations properly. See Fig. 5 for key to stratigraphic unit symbols. 
The southwestern end of the East Fork Ridge syncline is offset by an array of faults that project farther into the footwall of the Kingston thrust sheet than anywhere else along the trace of the WM fault. The faults are located primarily within and to the south of McKinney Ridge. This zone of faulting is bounded to the southwest and north by a fault that, for the purpose of discussion, is named the K-25 fault (Fig. 7). In map view, the fault projects off the mapped trace of the WM fault striking to the northwest and then changes strike toward the northeast, where displacement decreases to zero at the tip line. The position of the fault to the north of McKinney Ridge is fairly well constrained by the truncation of Knox Group rock units. The location of the fault towards the northeast is fairly well-constrained based on bedrock attitudes in the Chickamauga carbonates, but it may continue down the valley parallel to the strike of bedding. The position of the fault to the southwest is the least certain, but its position continues to be better-constrained as more subsurface information about the K-25 Site area becomes available. Little can be inferred about the subsurface geometry of the K-25 fault, but down-plunge projections suggest that it dips beneath the East Fork Ridge syncline.

The geometry of the southwestern hinge of the East Fork Ridge syncline has been modified by displacement along the K-25 fault. Fault displacement appears to have caused a clockwise rotation of the fold hold hinge towards the northwest (Fig. 6). In addition, fault displacement has offset the syncline fold hinge in the Chickamauga carbonates and transported it towards the northwest. The Chickamauga carbonates in the plant area are folded not into a single large syncline but into an anticline and syncline pair. (See the B-B' cross section shown in Fig. 8.) Although the folds are open and not overturned, the orientation of the map-scale folds is similar to the larger East Fork Ridge syncline. The folds trend and plunge very gently to the northeast under the plant area. Numerous outcrop-scale folds and faults occur within the area and probably formed as a means to accommodate the shortening within the folded carbonates. Although offset on the faults observed in outcrop is commonly small, a few of the faults could have a significant amount of displacement.

A map of mesoscopic folds and faults found in outcrops across the area depicts a consistent zone of deformation that extends to the southwest, subparallel to the northeast striking portion of the K-25 fault (Fig. 9). The zone is located within the upper part of the Carters Limestone and may correlate with the northeast-striking portion of the K-25 fault. In order for the fault to extend in this direction, however, displacement must be decreasing along the fault to the southwest, because faulting has not disrupted formations in the Knox Group. Additional evidence for the presence of the fault at depth, however, may be the development of the syncline-anticline pair present in the Chickamauga carbonates in the K-25 Site area. In order for folding to occur in the carbonates, a fault must exist in the subsurface that detaches the overlying folded carbonates from the underlying rocks. The deformed zone in the upper Carters Limestone may be the location where the fault intersects the land surface. If this hypothesis is correct, then the northwest striking portion of the K-25 fault may not be continuous with the northeast-striking portion, but a different fault entirely that was truncated and offset by this northeast-striking thrust fault. Additional subsurface information is needed to constrain the above hypothesis, and therefore a continuous fault zone is not plotted on the preliminary geologic map.

In the hanging wall, the presently mapped K-25 fault cuts steeply through fault slices of the Rome Formation, Copper Ridge Dolomite, Chepultepec Dolomite and then through a 


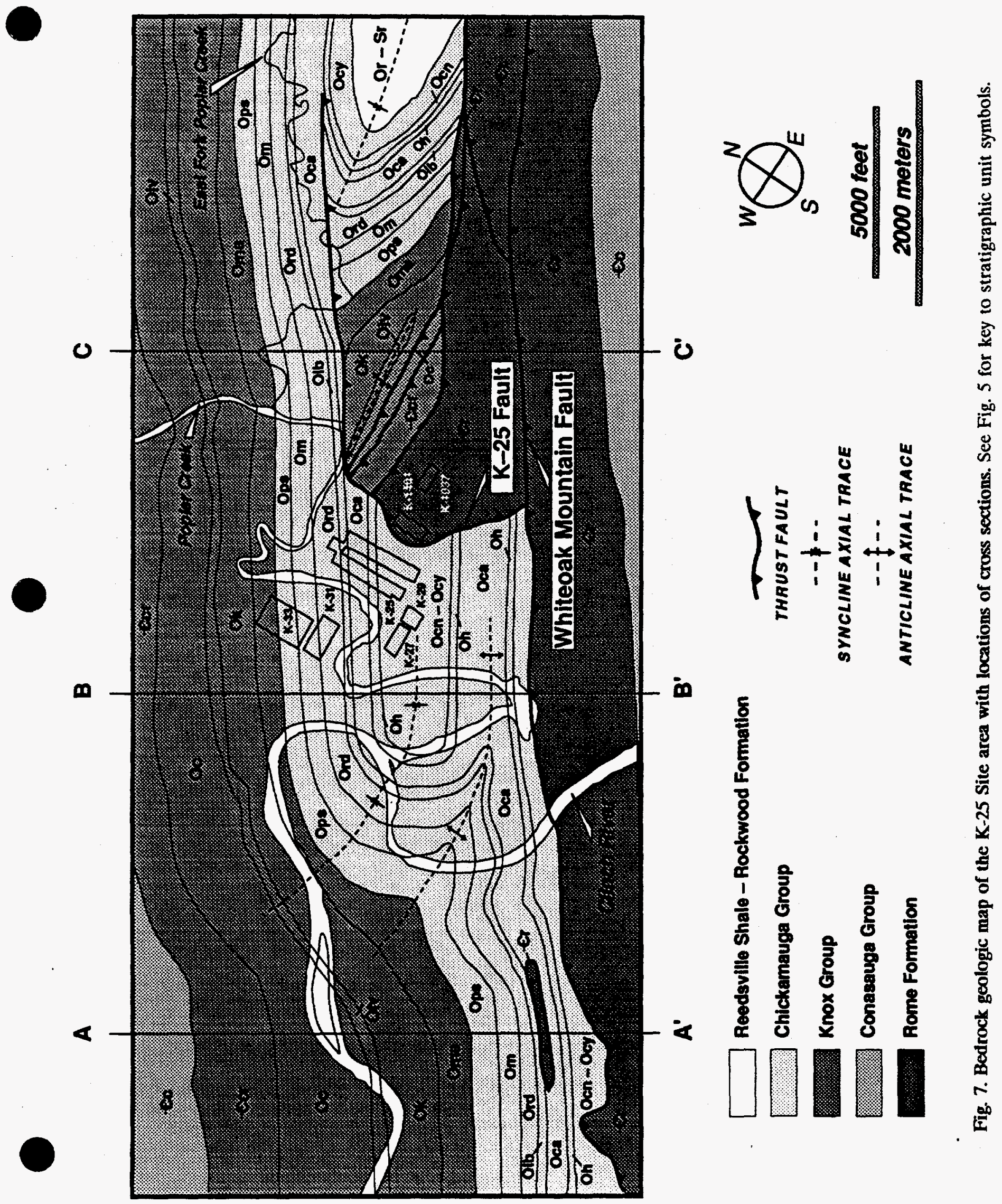




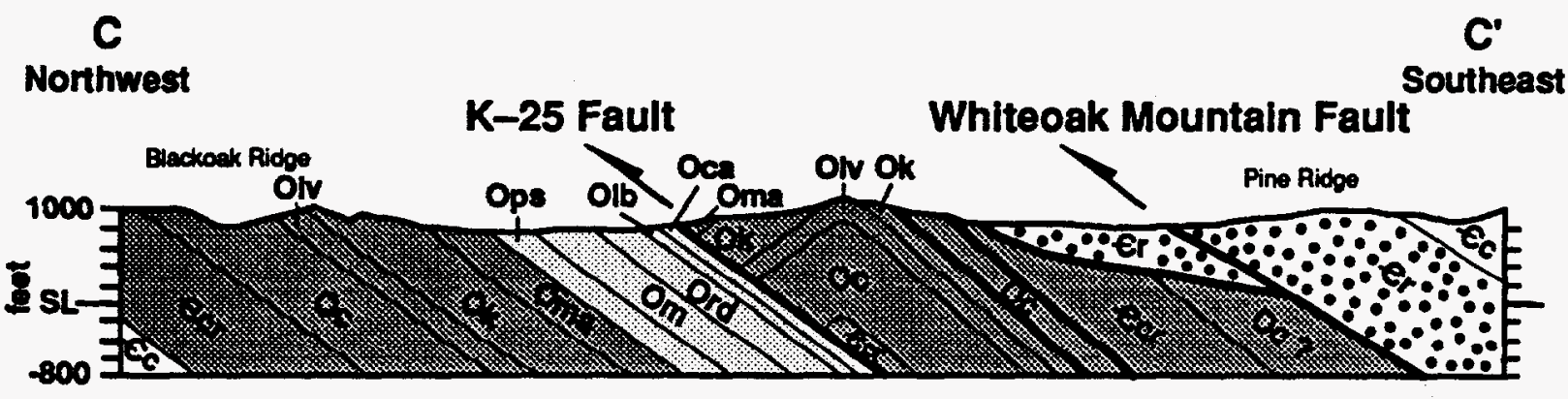

B

B'

Northwest Hypothesized Location of the K-25 fault

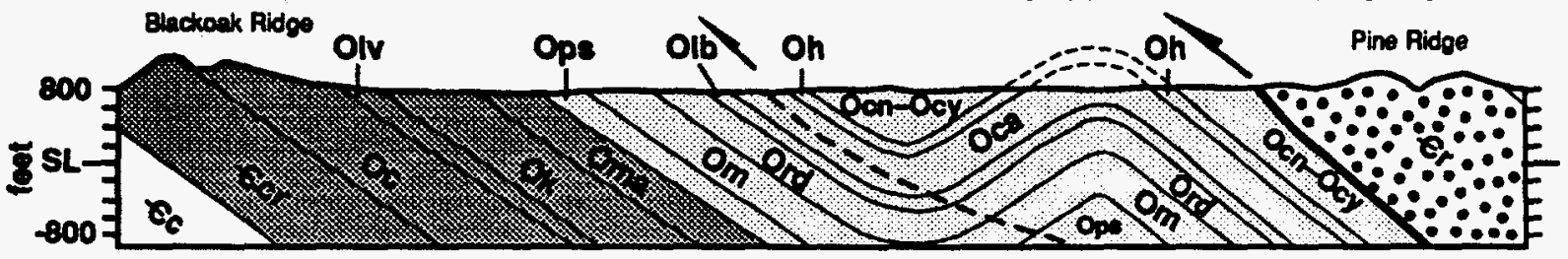

A

Northwest

Southeast

Whiteoak Mountain Fault
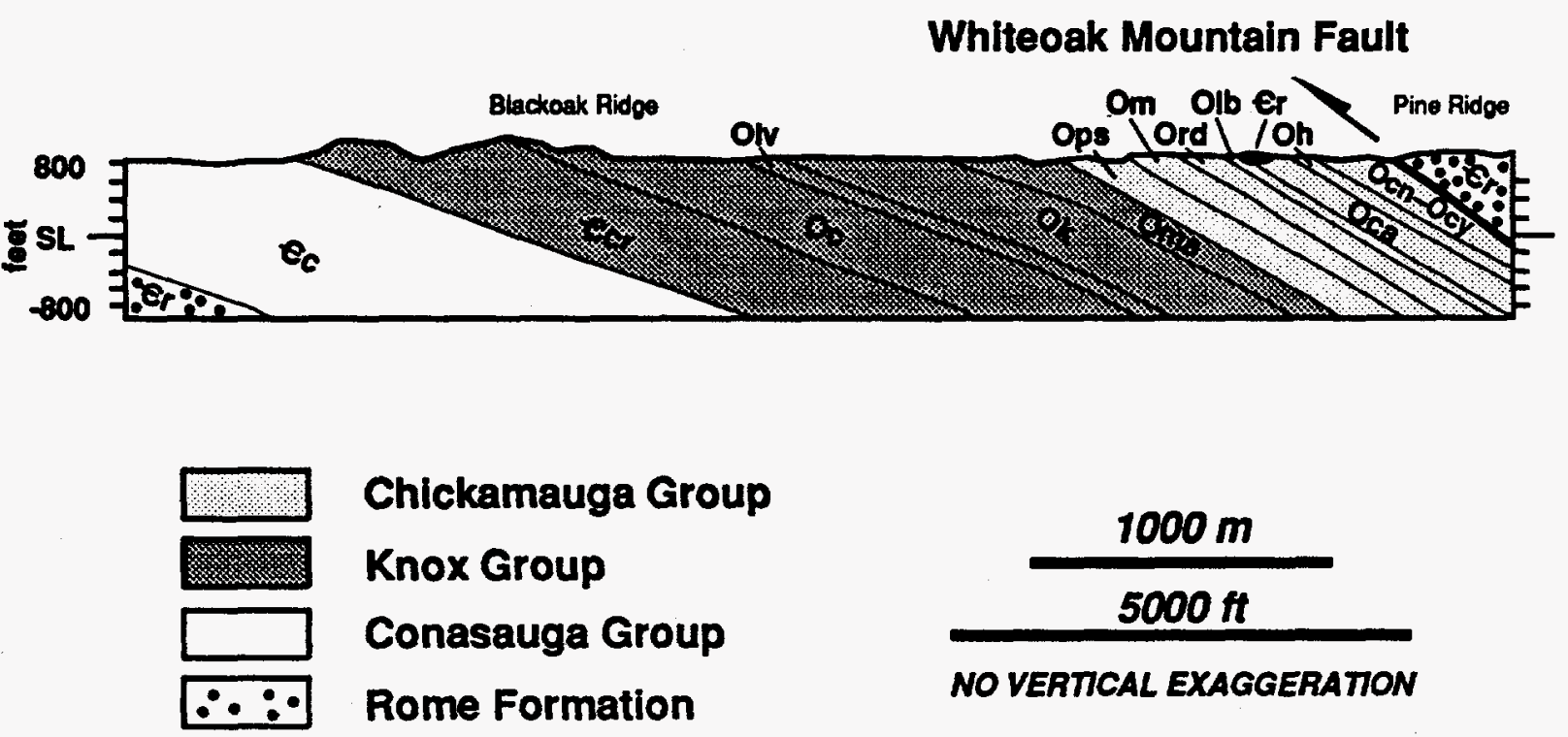

Fig. 8. Geological cross sections across the K-25 Site area. See Fig. 5 for key to stratigraphic unit symbols. 

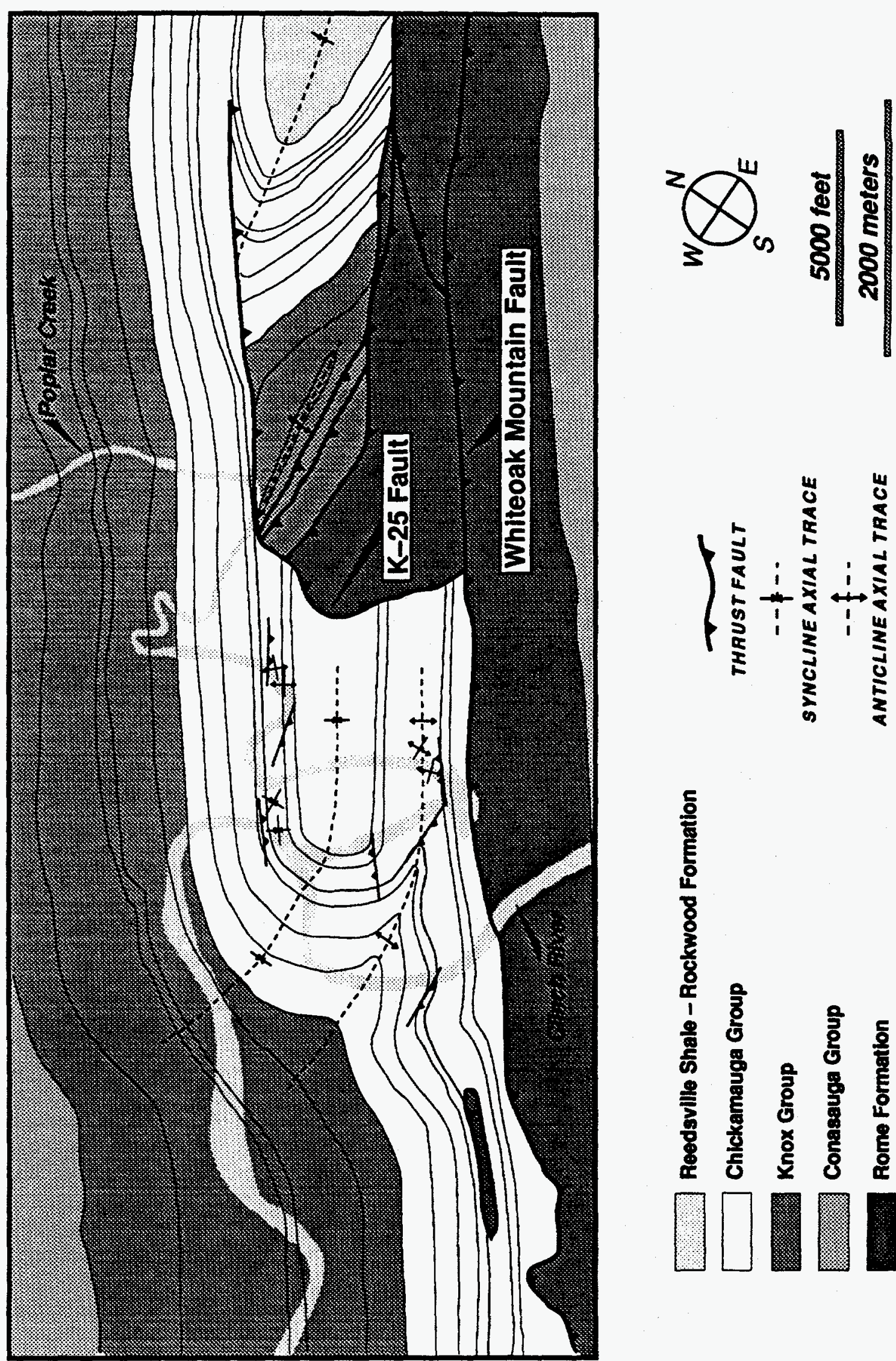

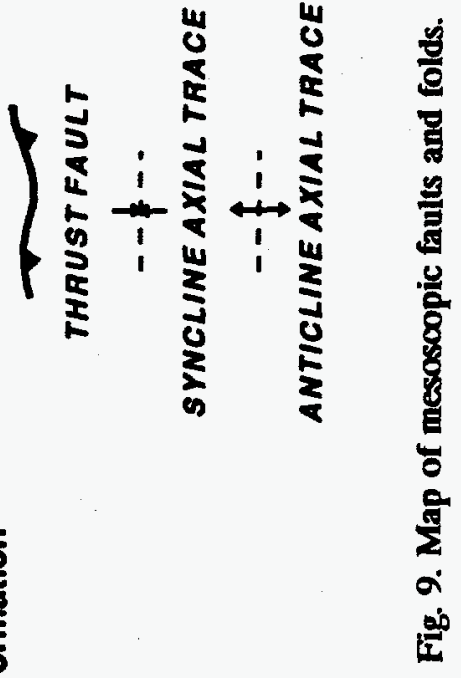

8

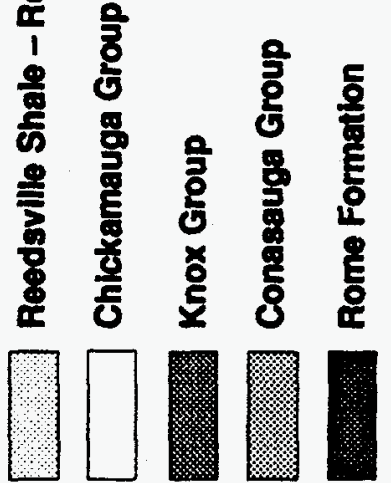


folded sequence of the Kingsport Formation and Longview Dolomite that continues into the Chickamauga Supergroup. (See the C-C' cross section shown in Fig. 8.) In the footwall, the fault cuts obliquely through folded bedding of the Chickamauga Supergroup and then strikes subparallel to bedding in the Carters Limestone. The fault cuts through bedding at a high angle because stratigraphic cutoffs in both the hanging wall and footwall are closely spaced. The footwall cutoffs that match those in the hanging wall are not evident in map view and therefore must exist in the subsurface. The amount of displacement along the $\mathrm{K}-25$ fault is unknown, but the direction of displacement along the fault is interpreted to be primarily towards the northwest because that was the regional shortening direction. Assuming northwest-directed displacement therefore requires that the northwest-striking portion of the fault be an oblique ramp and the northeast-striking portion of the fault be a frontal thrust.

Bedding orientations within the fault-bounded slice of the Rome Formation in the Grid D5 area (see Appendix B) suggest that it is complexly deformed by mesoscopic folds and faults. The slice appears to comprise primarily lower Rome shales, but the low hills are underlain by upper Rome sandstones. Except where the slice is truncated by the K-25 fault, the areal extent of the slice is not tightly constrained, because of the lack of surface exposures. A number of observations, however, indicate that the fault-bounded slice of the Rome sits on top of Chickamauga carbonates and may be relatively thin. First, approximately along strike to the southwest is a small fault-bounded slice (klippe) of the Rome Formation that sits on top of Chickamauga carbonates. Erosion through the lower Rome shales in the area exposed Chickamauga carbonates at relatively shallow depths. Similar fault-bounded slices of Rome sitting on carbonates are at various points along the trace of the WM fault (Hardeman 1966). Second, a few bedrock well logs in the area indicate that parts of the Rome are thin and may sit on top of carbonates. Third, regional structural relationships associated with the WM fault have been used to hypothesize that the fault had a late episode of movement that may have emplaced a continuous slice of the Rome Formation all along the footwall, which has now been dissected by erosion (Lemiszki and Hatcher 1992). The strong contrast in rock types across the fault zone suggests that the size and geometry of the fault slice could be accurately delineated with a combination of drilling and surface geophysical surveys.

One of the faults mapped in the Knox Group on McKinney Ridge is well exposed in the abandoned quarry off Blair Road. In the quarry, the fault is oriented approximately N70E / 66 SE, and juxtaposes the middle (?) part of the Chepultepec Dolomite against the upper part of the Kingsport Formation and therefore has accommodated some thrust displacement. Beds in both the hanging wall and footwall are variably folded, faulted, and fractured adjacent to the fault. Another reverse fault that places the Copper Ridge Dolomite against the Chepultepec Dolomite is interpreted to cut through a poorly exposed portion of the quarry. Previous studies of bedrock well logs in the area have been used to suggest that the fault slice of Copper Ridge Dolomite may contain a continuous sequence into the upper Conasauga Group on the south side of McKinney Ridge, but additional drilling is needed to test this hypothesis. One line of evidence that suggests that the McKinney Ridge structures are continuous on the south side of Blair Road is the similar bedrock attitudes measured in shales along the upper reaches of Mitchell Branch. Although shales in Mitchell Branch are mapped as Rome, there was not enough exposure to determine whether they are actually Conasauga Group shales that are either in a another thrust slice or part of a continuous sequence below the Copper Ridge Dolomite off of McKinney Ridge. Total displacement on the faults in the 
Knox Group is unknown, but may be minor because the faults are cutting steeply through bedding with little stratigraphic separation.

\subsection{BEDROCK FRACTURE SYSTEM}

Bedrock groundwater flow on the ORR occurs primarily through a system of open and connected fractures (Solomon et al. 1992). Therefore, various attributes of the bedrock fracture system must be known in detail to best interpret groundwater flow tests and model contaminant plume migration. Previous studies of the bedrock fracture system on the ORR have concluded that the fractures are not randomly oriented, but belong to distinct sets (Hatcher et al. 1992). Each fracture set is defined by a consistent orientation, style, and crosscutting relationship with other fracture sets within a particular area. Establishing the existence of distinct fracture sets is important because of the possibility of highly anisotropic fracture permeabilities and their control on karst conduit development. Since no previous work has been done, information pertaining to the fracture system in the K-25 Site area was collected during geologic mapping.

Time constraints prevented a complete fracture analysis of most outcrops during field mapping. Therefore, in order to acquire a data set representative of the fracture system in the area, fracture orientation data were collected by the selection method (Davis 1984). The method involves identifying individual fracture sets in each outcrop and taking one or two measurements to document the range in orientation of each set. A total of 114 fracture set measurements, primarily in the carbonates of the Chickamauga Supergroup were recorded by this method. Besides orientation, information pertaining to fracture type, timing, aperture, mineralization, and host rock type were recorded for each fracture set. The following discussion describes the characteristics and presents preliminary interpretations of the fracture system in the area. Future work on a number of outcrops, however, is needed to characterize the attributes of each fracture set more precisely.

The fracture system in the K-25 Site area consists of regional fracture sets that are similar to those mapped throughout the ORR and local fracture sets related to folding and faulting. In order to accommodate the background of the reader, the fracture orientation data are presented in four different ways: (1) a map of fracture strikes (Fig. 10), (2) a stereonet plot of poles to fracture planes, (3) a rose diagram of fracture strikes, and (4) a graph of fracture dip angle vs fracture azimuth (Fig. 11). All of the plots attest to the presence of a complex fracture system in the area, which is only beginning to be understood.

The map of fracture strikes is the most useful because it displays changes in fracture orientation across the area and how the fracture orientation relates to the bedrock geology (Fig. 10). Fracture strikes that are parallel and perpendicular to bedrock strike are representative of two major fracture sets in the area. These fracture sets have average strike and dips of N60 / 50NW and N30W / 90. Although more data are needed, orientation of each fracture set appears to rotate systematically across the plant area with changes in bedding strike. This is one reason for the wide distribution of fracture orientations seen on the other fracture plots. These fracture sets have been identified throughout the ORR and have been interpreted to have formed prior to the development of the thrust belt. Northeast of the plant area, previous work in the Kingston thrust sheet and East Fork Ridge syncline concluded that 


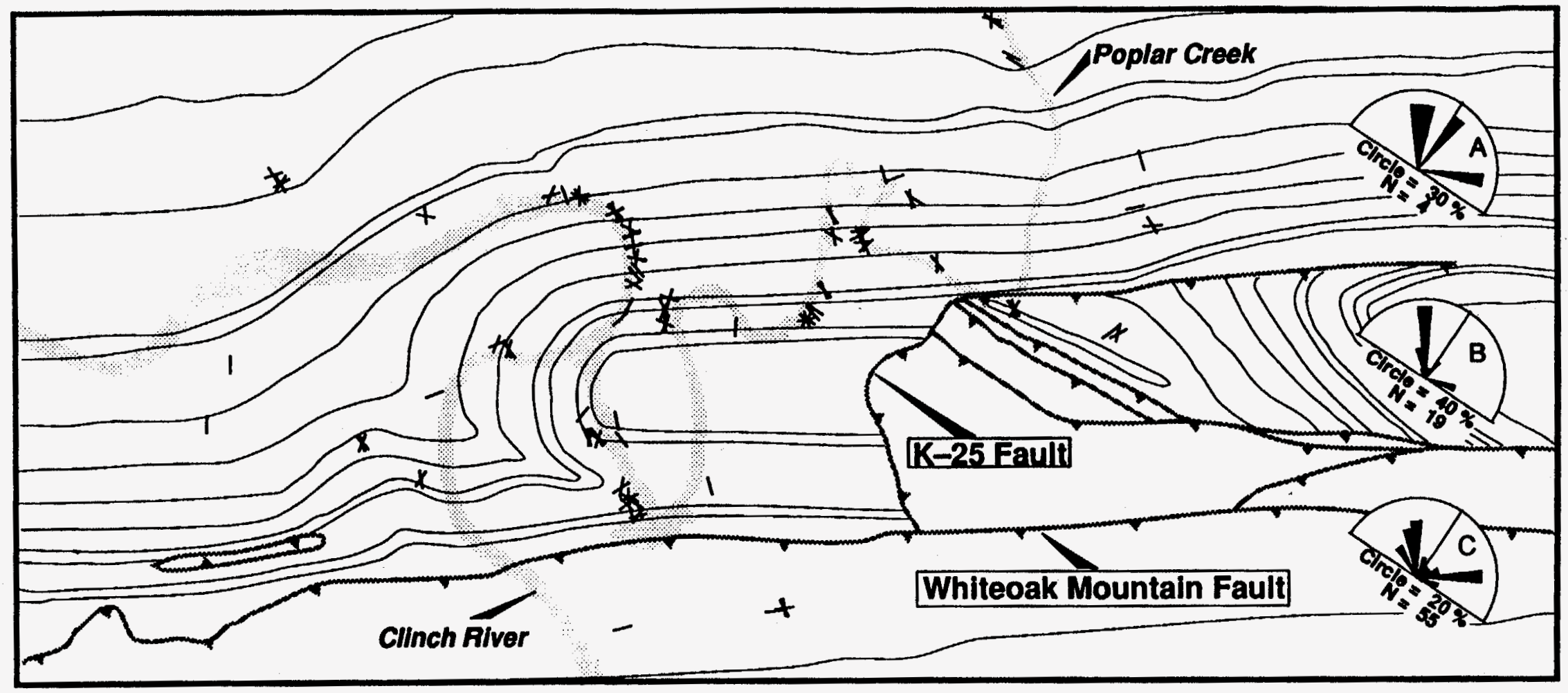

\section{Stratigraphic Contact}

\section{Thrust Fault}

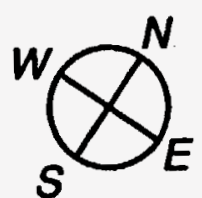

Fracture Strike Directions

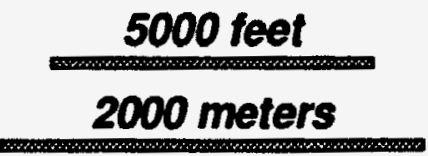

Fig. 10. Map of fracture set strikes measured in outcrops across the K-25 Site area. Inset $A$ is a rose diagram of fracture strikes from Blackoak Ridge. Inset $B$ is a rose diagram of fracture strikes from the southwest end of the East Fork Ridge syncline. Inset $C$ is a rose diagram of fracture strikes from the Rome Formation in the Whiteoak Mountain thrust sheet. 

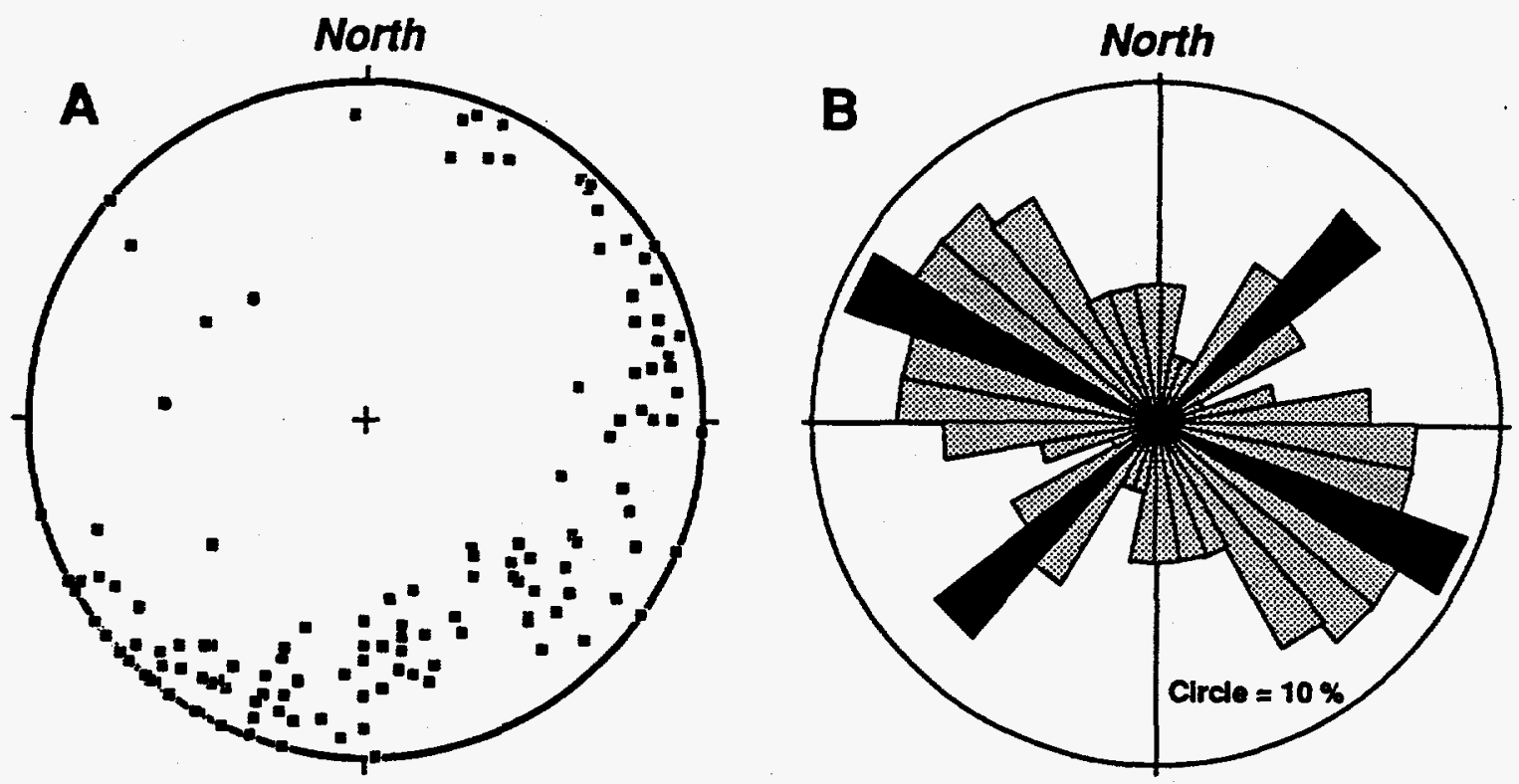

Number of Fracture Set Measurements $=144$

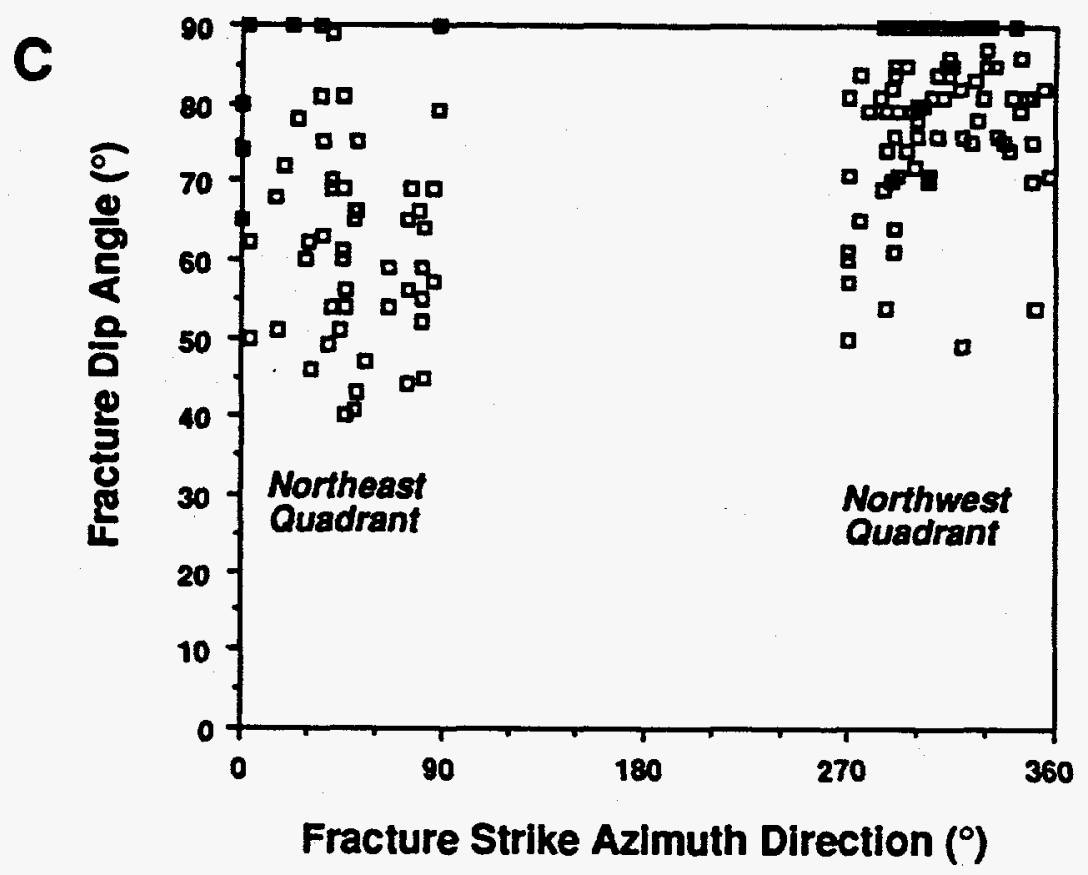

Fig 11. Fracture data plots for the K-25 Site area. Plate $A$ is an equal area, lower hemisphere, stereonet plot of poles to fracture set planes. Plate B is a rose diagram of fracture set strikes. Plate $C$ is an $x-y$ plot of fracture strike azimuth vs fracture dip angle. 
the two dominant fracture sets have an average strike and dip of $\mathrm{N} 65 \mathrm{E} / 53 \mathrm{NW}$ and N30W / 89NE (Hatcher et al. 1992).

The regional fracture sets consist primarily of extension fractures. The fractures are commonly oriented perpendicular to bedding, and although they may continue through a number of carbonate beds, they terminate at bed contacts where there is a distinct change in sedimentologic characteristics (i.e., lithology, bed thickness). The fractures are commonly widely spaced individual breaks, but zones of closely spaced fractures also occur. Many of the fractures are now open, but the presence of numerous calcite-filled fractures suggests that they were once all sealed and may be commonly sealed at depth. Calcite-filled fractures have apertures ranging from less than $1 \mathrm{~mm}$ to as much as $2 \mathrm{~cm}$. Weathering of the calcite filling and surrounding rock has greatly enlarged the aperture measured in open fractures.

Overprinting the regional fracture sets are arrays of shear fractures that are more abundantly developed in the K-25 Site area than in any other part of the ORR. Shear fractures differ from the regional extension fracture sets because displacement is primarily parallel to the walls of the fracture. Shear zones range from single, discrete fractures to wide zones consisting of conjugate arrays of en echelon tension gashes (Fig. 12). The zones are commonly perpendicular to bedding. Shear zones indicative of both left-lateral and right-lateral strike slip displacement have been observed based on mineral filling geometries and offset chert markers. The development of shear fracture zones is closely related to folding and faulting in the area. Therefore, the relative distribution and geometry of shear fracture zones may be a useful way to detect the location of unknown faults. Much more information needs to be collected about these zones before their influence on groundwater flow can be ascertained. More studies are needed to determine (1) their distribution across the area; (2) the variables that control their overall dimensions, both parallel and perpendicular to bedding; and (3) the factors that control the development of long, continuous shear fractures vs shear zones of short, disconnected en echelon tension gashes. 


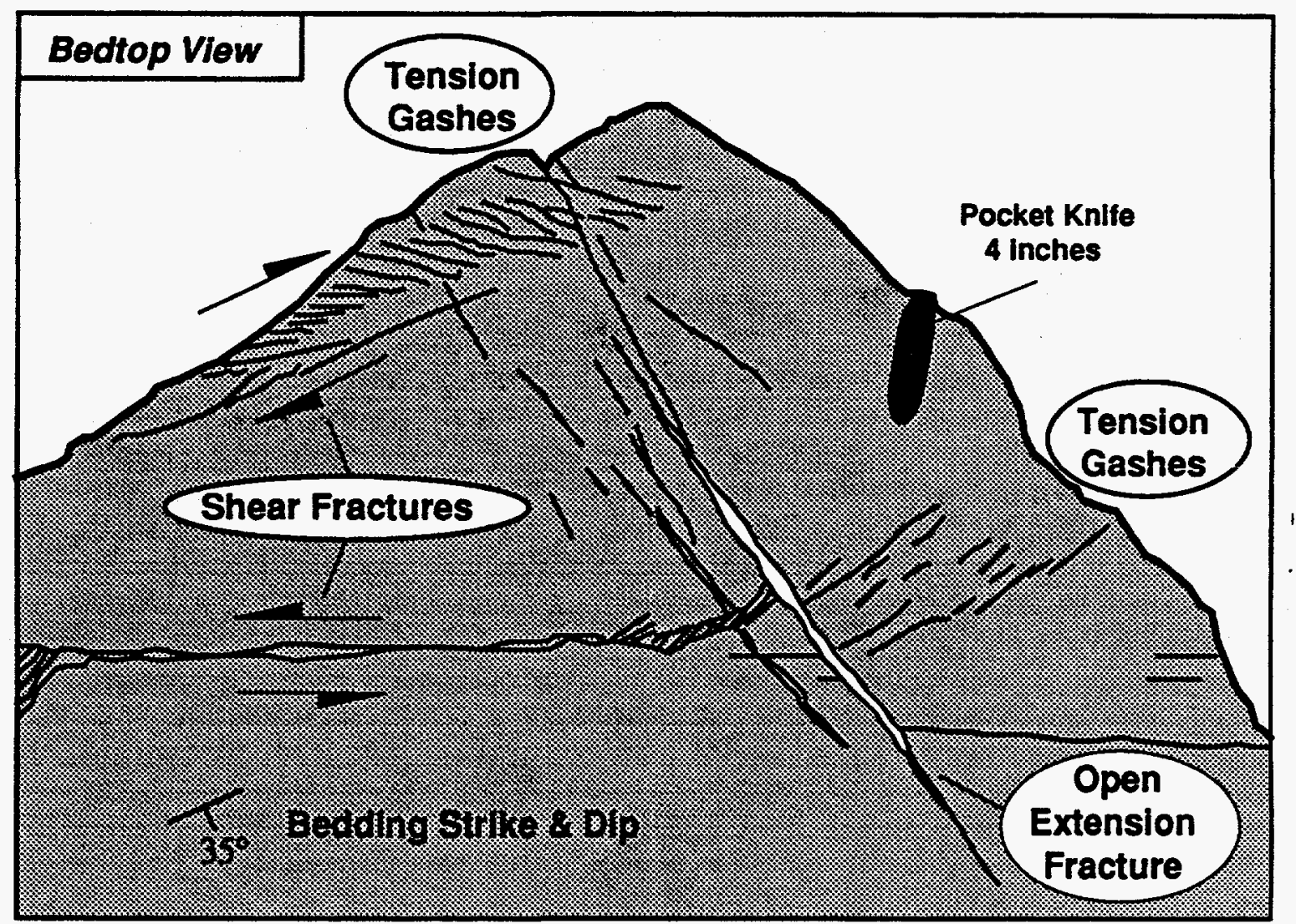

Fig. 12. Sketch from a photograph of an outcrop in the Murfreesboro Limestone. The style of extension and shear fracture sets observed in the K-25 Site Area is illustrated. 


\section{KARST LANDFORMS, SEEPS, AND SPRINGS}

A number of karst landforms, seeps, and springs were encountered during field mapping (Fig. 13). Because of their importance in characterizing the groundwater system in the area, the location and general characteristics of these features were noted and can be used as a preliminary data base for future karst studies. Although a more complete karst study is needed, none of the karst features appeared to be preferentially developed within any particular stratigraphic unit. For simplicity, the term spring is used throughout the following text.

Open cavities ranged from bedrock exposures with human-sized enterable openings to small drains at the bases of sinkholes. The cave located on Blackoak Ridge in the Copper Ridge Dolomite is called Winkin Cave and has been explored and mapped (Bruce Zerr, personal communication 1993). This cave may be representative of those that develop in the Knox Group on Blackoak Ridge and should be more thoroughly studied. Some of the other open cavities were examined (Paul Rubin, personal communication 1993) to determine if they could be used as entry points into an underlying a cave system. Based on this analysis, the only cave that was enterable and extended any distance is located on McKinney Ridge near East Fork Creek (Fig. 13).

The majority of springs mapped are located along the banks of the Clinch River in the Chickamauga Supergroup. Most of the year the springs are underwater, but the springs were exposed because most of the mapping occurred during the winter low stage of the Clinch River. Springs ranged from water flowing out of bedrock openings to large water-filled potholes in the river bank flats. The potholes were actively filling at their base and overflowing at the tops to drain into the nearby river. Spring flows ranged from small trickles of water to estimated flows of as much as $25 \mathrm{gal} / \mathrm{min}$. The locations of the springs encountered were mapped as accurately as possible so that they could be revisited for future water sampling. In addition, detailed knowledge of the location of underwater springs in the Clinch River can be used to test for suitable methods that can detect underwater springs in the area. A few springs were also mapped in drainages off of hills underlain by the Rome Formation.

One sinking stream was found during mapping (Fig. 13). The location of the sinking stream is on the southeast side of Blackoak Ridge at the corner of East Fork and Herrell roads. The stream is fed from a catchment on the ridge and sinks into a cavity in the Mascot Dolomite at the base of the ridge near the contact with the Pond Spring Formation. The exact location of the spring related to the sinking stream is unknown, but some springs were located towards the southwest near East Fork creek. 

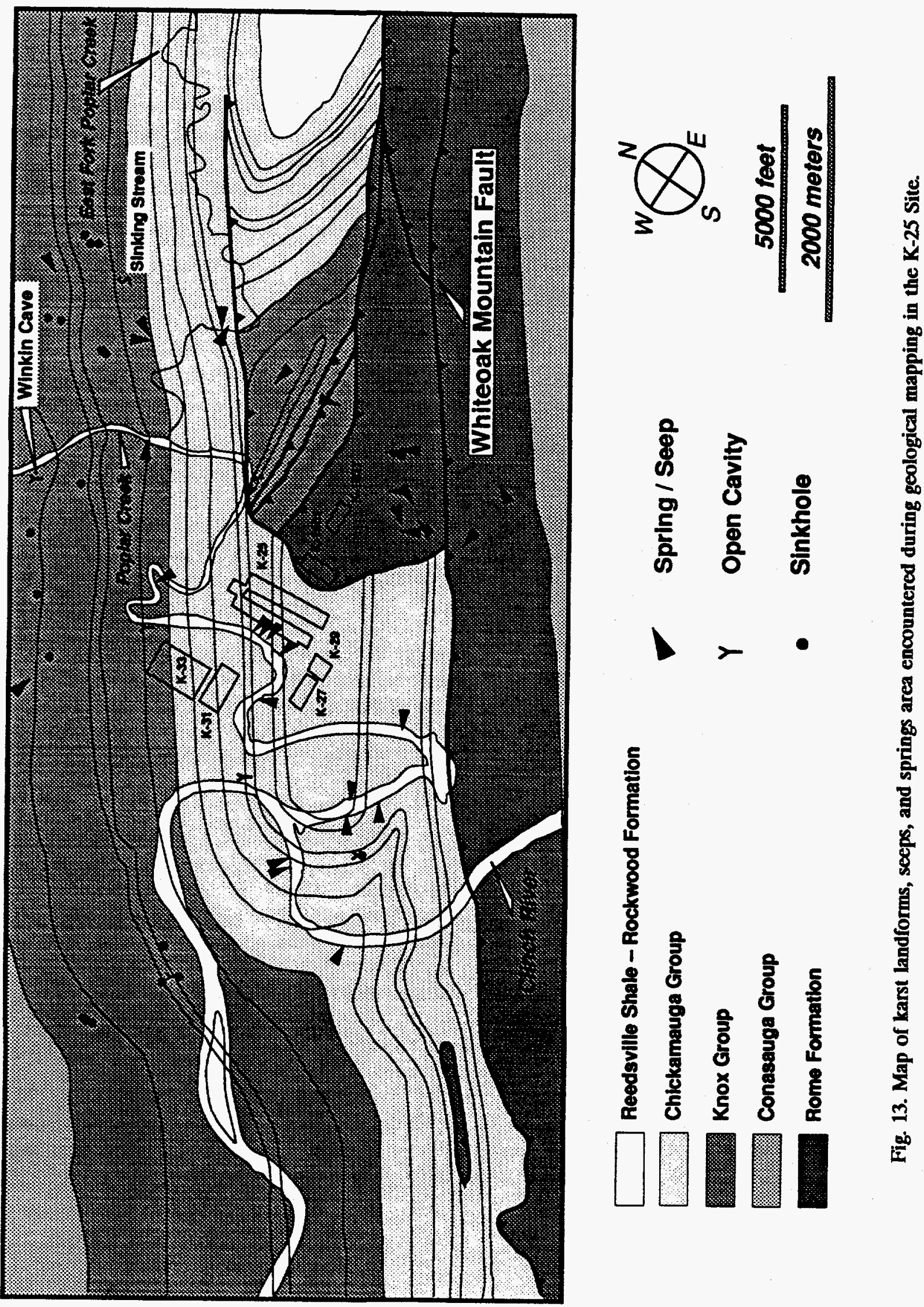


\section{SUMMARY AND SUGGESTIONS FOR FUTURE WORK}

The primary goal of site geologic studies should be to develop a thorough and defensible understanding of the K-25 Site geology and how it relates to the groundwater flow system. Geologic mapping is the first step toward attaining this goal and will provide the framework in which to develop and interpret future detailed geologic and groundwater studies.

Geologic mapping in the K-25 Site area has resulted in better definition of the location of contacts between the major rock units (Rome Formation, Knox Group, and Chickamauga Supergroup) and allowed for division of the Knox Group and Chickamauga Supergroup into mappable units based on field criteria. In addition, excellent exposures of the Chickamauga Supergroup along the Clinch River and East Fork Poplar Creek has lead to a better understanding of the rock types composing the individual formations.

As expected, the structures within the plant site are complex and appear to consist of an anticline and syncline pair affecting only rocks of the Chickamauga Supergroup. The amount of internal deformation (faulting) within the anticline and syncline, however, is poorly constrained. Similarly, because of poor exposure, the location of the WM fault has not been constrained any more precisely than in previous maps. Finally, a preliminary analysis of the fracture system in the area indicates the presence of the reservation-wide regional fracture sets, as well as the development of an extensive array of shear fractures related to the local folds and faults.

As indicated above, more information needs to be gathered concerning a number of factors related to the site geology. The sections that follow comprise a partial list of recommendations for future geologic studies that should lead to a better understanding of the plant geology.

\subsection{BEDROCK CORE DRILLING AND GEOPHYSICAL WELL LOGGING}

Drilling should intersect a number of key targets, both stratigraphic and structural, to begin constraining subsurface structural interpretations related to: (1) the hypothesized fault underlying the folded carbonates in the plant area, (2) the geometry of the K-25 and Whiteoak Mountain faults, (3) the lateral and vertical extent of the fault slice of the Rome Formation, and (4) the extent of internal faulting within folded carbonates in the plant area.

Subsurface stratigraphic and structural relationships determined from drilling can be combined with surface maps to create detailed cross sections and block diagrams.

Coring is needed to characterize the style, distribution, and geometry of mesoscopic structures in the subsurface, such as fractures, folds, faults, and stylolites, and their relationship to bed thickness, lithology, structural position, and depth. 
The development of coring-induced fractures in rock cores can be used to estimate the orientation of the in-situ stress field, which, depending upon its orientation, can affect the effective aperture of certain fracture sets.

\subsection{OUTCROP STRUCTURAL ANALYSIS}

Fracture development has a strong influence on both solution development in the carbonates and preferential groundwater flow paths in the noncarbonates. The purpose of outcrop structural analysis is to relate the characteristics of the local fracture system to the mechanical characteristics of the stratigraphy and regional and local structural history. The study should incorporate a combination of detailed outcrop fracture mapping (orientation, spacing, lengths, etc.); petrographic analysis of veins to determine fracture opening modes; timing relationships; initial apertures; local secondary porosity characteristics; and mineral filling compositions. The information can then be used to: (1) evaluate which rock units will have the potential for enhanced fracture porosity and permeability, (2) predict units with potential confining capabilities, (3) predict potential conduit orientations, and (4) develop an understanding of the changes in open fracture development with depth.

\subsection{OUTCROP STRATIGRAPHIC ANALYSIS}

Outcrop stratigraphic analysis is needed to provide a more detailed description of each rock unit in the K-25 Site area. Sedimentologic studies should include (1) measurement of true stratigraphic thicknesses, (2) documentation of lithologic characteristics, (3) evaluation of the potential for lateral and vertical facies changes within each rock unit, and (4) thinsection analysis to determine rock mineral constituents and their chemical composition. Such studies are needed prior to or in conjunction with drilling to help interpret and correlate core descriptions within a larger depositional framework.

\subsection{MATRIX POROSITY ANALYSIS}

Although primary matrix porosity is very low in the rock units on the ORR, secondary matrix porosity is closely related to depth, composition, and local geologic relationships associated with a particular rock unit. Secondary and primary matrix porosity values are needed for modelling diffusional transport of contaminants and are closely related to the development of conduits in certain rock units. Matrix porosity values can be obtained by two easy and inexpensive methods. First, point-counting pore spaces during petrographic analysis of outcrop and core samples is a direct means of determining the matrix porosity of a particular sample and relating it to diagenetic relationships observed in the sample. Second, porosity analysis by the weight-reduction method can provide estimates of total porosity that can be compared with thin-section estimates.

\subsection{GEOLOGY AND KARST DEVELOPMENT}

An effort should be made to correlate karst landforms and features in bedrock well logs with particular stratigraphic units. Mature karst aquifers tend to be nonhomogeneous and 
anisotropic when subjected to intensive weathering and where stratigraphy, structure, and topography contribute to complex permeability and porosity distributions. In the K-25 Site area, the distribution of conduits within the stratigraphic column should provide a measure of the solutioning in each type of carbonate and therefore measure the amount of lithologic control exerted on solution development. Factors influencing the development of intergranular, vugular, and fracture-controlled porosity and permeability should be of interest because they may account for the size and distribution of solution openings and contribute to the gross transmissive and storage characteristics of the aquifer. Furthermore, detailed geologic and hydrologic cave mapping may provide insight on some of the local geologic controls on karst development. 


\section{REFERENCES}

Bassler, R. S. 1932. The stratigraphy of the Central Basin of Tennessee. Tennessee Division of Geology Bulletin. 38.

Beets, J. W. 1985. Structural analysis of the Hunter Valley, Wallen Valley, and Whiteoak Mountain fault intersection in northeastern Tennessee. M.S. thesis. University of Tennessee, Knoxville.

Borowski, W: S. 1982. Petrology, depositional environments, and stratigraphic analysis of a part of the Middle Ordovician Chickamauga Group limestones near Clinton, Tennessee. M.S. thesis. University of Tennessee, Knoxville.

Butts, C. 1926. The Paleozoic rocks. pp. 41-230. In G. I. Adams, C. Butts, L. W. Stephenson, and W. Cooke, Geology of Alabama. Geological Survey of Alabama, Special Report No. 14.

Davis, G. H. 1984. Structural Geology of Rocks and Regions. Wiley, New York.

Fenneman, N. M. 1938. Physiography of the Eastern United States. McGraw-Hill, New York.

Fox, P. P. and L. F. Grant. 1944. Ordovician bentonites in Tennessee and adjacent states. Journal of Geology. 52:319-332.

Geraghty \& Miller, Inc. 1989. Hydrogeology of the Oak Ridge Gaseous Diffusion Plant. K/Sub/85-22224/12. Oak Ridge Gaseous Diffusion Plant.

Ghazizadeh, M. 1987. Petrology, depositional environments, geochemistry, and diagenetic history of lower and middle Chickamauga Group (Middle Ordovician) along Highway 58, east Tennessee. Ph.D. dissertation. University of Tennessee, Knoxville.

Hardeman, W. D. 1966. Geologic map of Tennessee, east-central sheet. Scale 1:250,000. Tennessee Division of Geology and United States Geological Survey.

Harris, L. D. 1973. Dolomitization model for upper Cambrian and lower Ordovician carbonate rocks in the eastern United States. U.S. Geological Survey Journal of Research. 1:63-78.

Hatcher, R. D., Jr. 1987. Tectonics of the southern and central Appalachian internides. Annual Reviews of Earth and Planetary Sciences. 15:337-362.

Hatcher, R. D., Jr., P. J. Lemiszki, R. B. Dreier, R. H. Ketelle, R. R. Lee, D. A. Lietzke, W. M. McMaster, J. L. Foreman, and S. Y. Lee. 1992. Status Report on the Geology of the Oak Ridge Reservation. ORNL/TM-12074. Oak Ridge National Laboratory.

Hayes, C. W. 1891. The overthrust faults of the southern Appalachians. Geological Society of America Bulletin. 2:141-153. 
Hayes, C. W. 1894. Ringold Quadrangle. Scale 1:24,000. Geologic Atlas Folio, No. 2. U.S. Geological Survey.

Hayes, C. W. and Ulrich, E. O. 1903. Description of the Columbia quadrangle, Tennessee. Scale 1:24,000. U.S. Geological Survey Atlas Folio, No. 95.

Jones, C. K. 1963. Structure along the Whiteoak Mountain fault near Kingston, Roane County, Tennessee. M.S. thesis. University of Tennessee, Knoxville.

Kemp, T. O. 1954. A study of the Middle and Lower-Upper Ordovician rocks of the Oak Ridge Valley between Elza Gate and Clinton; Anderson County, Tennessee. M.S. thesis. University of Tennessee, Knoxville.

Lemiszki, P. J. and R. D. Hatcher, Jr. 1992. Structural analysis of the Copper Creek and Whiteoak Mountain faults in east Tennessee: Implications for the thrusting sequence and growth of the southern Appalachian foreland fold-thrust belt. Geological Society of America Abstracts with Programs. 24:A362.

McMaster, W. M. 1957. The geology of East Fork Ridge and Pilot Knob, Oak Ridge Anderson County, Tennessee. M.S. thesis. University of Tennessee, Knoxville.

McMaster, W. M. 1962. Geologic Map of the Oak Ridge Reservation, Tennessee. Scale 1:31,680. ORNL/TM-713. Oak Ridge National Laboratory.

McReynolds, J. A. 1988. Paleoenvironment and facies relations of the Lower Cambrian Rome Formation along Haw Ridge on the U.S. Department of Energy Reservation, Oak Ridge area in Roane and Anderson Counties, Tennessee. M.S. thesis. University of Tennessee, Knoxville.

Milici, R. C. and J. W. Smith. 1969. The stratigraphy of the Chickamauga Supergroup in its type area. Tennessee Division of Geology Report of Investigations No. 24.

Ossi, E. J. III. 1979. Mesoscopic structures and fabric within the thrust sheets between the Cumberland escarpment and Saltville fault. M.S. thesis. University of Tennessee, Knoxville.

Poling, R. S., P. A. Rubin, and P. J. Lemiszki. 1992. Hydrogeologic Characterization Plan for the Oak Ridge K-25 Site. K/EM-1. Oak Ridge K-25 Site.

Rankin, D. W., A. A. Drake, Jr., L. Glover III, R. Goldsmith, L. M. Hall, D. P. Murray, N. M. Ratcliffe, J. F. Read, D. T. Secor, and R. S. Stanley. 1989. The Appalachian-Ouachita orogen in the United States. In R. D. Hatcher, Jr., W. A. Thomas, and G. W. Viele, eds. The Geology of North America, F-2:7-100. Geological Society of America. Boulder, Colorado.

Rodgers, J. 1943. Geologic map of the Copper Ridge district, Hancock and Grainger Counties, Tennessee. 1:24,000. U.S. Geological Survey Stratigraphy and Mineral Investigations, Preliminary Map P.N. 31476. 
Rodgers, J. 1953. Geologic map of east Tennessee with explanatory text. Scale 1:125,000. Tennessee Division of Geology Bulletin. 58.

Safford, J. M. 1869. Geology of Tennessee. Nashville, Mercer.

Safford, J. M. and J. B. Killebrew. 1900. The Elements of the Geology of Tennessee. Nashville, Tennessee, Foster and Webb.

Samman, N. B. 1975. Sedimentation and stratigraphy of the Rome Formation in east Tennessee. Ph.D. dissertation. University of Tennessee, Knoxville.

Solomon, D. K., G. K. Moore, L. E. Toran, T. B. Dreier, and W. M. McMaster. 1992. Status Report: A Hydrologic Framework for the Oak Ridge Reservation. ORNL/TM-12026. Oak Ridge National Laboratory.

Spigai, J. J. 1963. A study of the Rome Formation in the Valley and Ridge Province of east Tennessee. M.S. thesis. University of Tennessee, Knoxville.

Ulrich, E. O. 1911. Revision of the Paleozoic systems. Geological Society of America Bulletin. 22:281-680.

Wilson, C. W. 1949. Pre-Chattanooga stratigraphy in Central Tennessee. Tennessee Division of Geology Bulletin. 56.

Wilson, R. L. 1986. Geologic map and mineral resources summary of the Ooltewah quadrangle, Tennessee. Scale 1:24,000. Tennessee Division of Geology, GM 112-SE. 
36

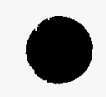

- 
Appendix A STRATIGRAPHIC AND STRUCTURAL DATA 
38 


\section{Appendix A. STRATIGRAPHIC AND STRUCTURAL DATA}

Table A-1 lists the grid location, rock unit, bedding orientation, and fracture set orientations recorded at each outcrop during field mapping. The following is an explanation of the table headings and abbreviations:

Station Station number recorded in field notes.

Grid Grid location based on S-16A topographic map.

Rock unit Stratigraphic group or formation; see Fig. 5 for symbol abbreviations.

Lithology $\mathrm{CH}=$ chert

$\mathrm{DOL}=$ dolomite

LS = limestone

$\mathrm{SH}=$ shale

$\mathrm{SS}=$ sandstone

Strike Positive numbers are northeast quadrant; negative numbers are northwest quadrant.

Dip Angel of dip from horizontal.

DD Dip direction. 
Table A.1. K-25 Site area stratigraphic and structural data

\begin{tabular}{|c|c|c|c|c|c|c|c|c|c|}
\hline & & & & \multicolumn{3}{|c|}{ FRACTURE } & \multicolumn{3}{|c|}{ BEDROCK } \\
\hline STATION & GRID & ROCK UNIT & LTHOLOGY & STRIKE & DIP & DD & STRIKE & DIP & DD \\
\hline 1 & A5 & Ock & DOL & 4 & 62 & $\mathbf{N}$ & 35 & 36 & $\mathrm{~s}$ \\
\hline 1 & A5 & Ock & $\overline{\mathrm{DOL}}$ & 80 & 55 & $\mathbf{N}$ & & & \\
\hline 2 & A5 & $\overline{O C k}$ & DOL & 52 & 75 & $\mathbf{N}$ & 62 & 39 & $\mathbf{s}$ \\
\hline 3 & A5 & Ock & $\mathrm{DOL}$ & & & & 60 & 45 & $s$ \\
\hline 4 & C5 & OCk & $\overline{D O L}$ & & & & 35 & 29 & $\mathbf{N}$ \\
\hline 5 & B6 & OCk & DOL & & & & 50 & 30 & s \\
\hline 6 & $\mathrm{~B} 6$ & OCk & $\overline{\mathrm{DOL}}$ & & & & 45 & 35 & $\mathbf{s}$ \\
\hline 7 & B6 & OCK & $\mathrm{DOL}$ & & & & 50 & 25 & $\mathrm{~S}$ \\
\hline 8 & B6 & Ock & $\mathrm{DOL}$ & -48 & 85 & $\mathbf{s}$ & 55 & 32 & s \\
\hline 9 & B6 & OCk & $\mathrm{CH}$ & & & & 65 & 45 & s \\
\hline 10 & A5 & OCk & $\overline{D O L}$ & & & & 44 & 34 & S \\
\hline 11 & A5 & Ock & $\mathrm{DOL}$ & & & & 42 & 37 & $\mathbf{s}$ \\
\hline 12 & A5 & Ock & DOL & & & & 50 & 31 & 5 \\
\hline 13 & D4 & Och & LS & & & & 61 & 32 & s \\
\hline 14 & D4 & Och & LS & & & & 80 & 52 & $\mathbf{N}$ \\
\hline 15 & D4 & Och & LS & & & & 70 & 18 & $\mathbf{N}$ \\
\hline 16 & D4 & $O_{\text {ch }}$ & LS & & & & & & \\
\hline 17 & D4 & Och & LS & & & & 5 & 11 & S \\
\hline 18 & D4 & Och & LS & & & & 66 & 59 & $\mathbf{s}$ \\
\hline 19 & D4 & Och & LS & & & & 70 & 62 & S \\
\hline 20 & $D 4$ & Och & LS & & & & 50 & 65 & $\mathbf{s}$ \\
\hline 21 & D4 & och & LS & & & & 64 & 39 & $\bar{N}$ \\
\hline 22 & D4 & Och & LS & & & & 78 & 22 & 5 \\
\hline 23 & D4 & Och & LS & & & & 60 & 55 & $\mathbf{s}$ \\
\hline 24 & D4 & Och & LS & & & & 50 & 52 & $\mathbf{N}$ \\
\hline 25 & D4 & Och & LS & & & & 32 & 44 & 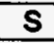 \\
\hline 26 & D4 & $\mathrm{Cr}_{r}$ & SSISH & -40 & 49 & $\mathbf{N}$ & -61 & 41 & $\mathbf{s}$ \\
\hline 26 & $\mathrm{D4}$ & $C_{r}$ & SSISH & -61 & 76 & 5 & & & \\
\hline 26 & $\mathrm{D} 4$ & $\mathrm{Cr}_{r}$ & SSISH & -55 & 71 & $\mathbf{N}$ & & & \\
\hline 26 & D4 & $C_{r}$ & SSISH & 50 & 41 & $\mathbf{N}$ & & & \\
\hline 27 & D4 & $\overline{C r}$ & SSISH & & & & 49 & 36 & $\mathrm{~s}$ \\
\hline 28 & $D 4$ & $\mathrm{Cr}_{r}$ & SSISH & & & & 45 & 61 & $\mathrm{~s}$ \\
\hline 29 & D4 & $\mathrm{Cr}_{\mathrm{r}}$ & SSISH & 51 & 66 & $N$ & 61 & 45 & s \\
\hline 30 & 84 & OCk & $\mathrm{CH}$ & & & & 60 & 74 & s \\
\hline 33 & B4 & Ock & $\mathrm{DOL}$ & & & & 15 & 33 & $S$ \\
\hline 34 & $\overline{D 3}$ & $\mathrm{Cr}_{\mathrm{r}}$ & SS & & & & & & \\
\hline 36 & $\mathrm{D} 3$ & $\mathrm{Cr}_{r}$ & SSISH & 40 & 89 & $\mathrm{~s}$ & 61 & 41 & $\mathbf{S}$ \\
\hline 37 & $\mathrm{D3}$ & Och & LS & & & & 75 & 65 & $\mathrm{~s}$ \\
\hline 38 & $\mathrm{D3}$ & $\mathrm{Cr}_{\mathrm{r}}$ & $\mathrm{SH}$ & & & & 75 & 55 & $\mathbf{s}$ \\
\hline 39 & C3 & Och & LS & 4 & 50 & $\mathbf{s}$ & -30 & 51 & S \\
\hline 40 & C.3 & Och & LS & -23 & 75 & $\mathbf{N}$ & 74 & 32 & $\mathrm{~N}$ \\
\hline 40 & C3 & Och & LS & -26 & 85 & 5 & & & \\
\hline 40 & $C_{3}$ & Och & LS & -46 & 84 & 5 & & & \\
\hline 41 & $C_{3}$ & Och & LS & & & & 82 & 27 & $\mathbf{N}$ \\
\hline 41 & C. & Och & LS & -72 & 70 & 5 & 70 & 25 & $\mathbf{N}$ \\
\hline 41 & $\mathrm{CB}$ & Och & LS & -65 & 74 & $\mathbf{s}$ & & & \\
\hline 41 & $\mathrm{CB}$ & Och & LS & 88 & 79 & $\mathbf{s}$ & & & \\
\hline 41 & C3 & Och & LS & -15 & 86 & S & & & \\
\hline 41 & C.3 & Och & LS & -86 & $?$ & $?$ & & & \\
\hline 42 & C3 & Och & LS & -58 & 80 & $N$ & 70 & 25 & $\mathbf{N}$ \\
\hline 43 & C.3 & Och & LS & & & & 60 & 40 & $\mathbf{N}$ \\
\hline $44 A$ & C.3 & Och & LS & & & & 60 & 20 & $s$ \\
\hline $44 B$ & $\mathbf{C 3}$ & Och & LS & & & & 61 & 15 & 5 \\
\hline 45 & $B 2$ & OCK & $\overline{D O L}$ & & & & -60 & 86 & $\mathbf{N}$ \\
\hline 46 & $B 2$ & OCk & $\mathrm{DOL}$ & & & & 46 & 28 & s \\
\hline 47 & 82 & OCk & $\mathrm{DOL}$ & -65 & 90 & $N$ & 14 & 35 & $s$ \\
\hline
\end{tabular}


41

Table A1 (continued)

\begin{tabular}{|c|c|c|c|c|c|c|c|c|c|}
\hline & & & & \multicolumn{3}{|c|}{ FRACTURE } & \multicolumn{3}{|c|}{ BEDROCK } \\
\hline STATION & GRID & ROCK UNIT & LTHOLOGY & STRIKE & DIP & $\overline{D D}$ & STRIKE & DIP & DD \\
\hline 47 & 82 & OCk & DOL & 40 & 70 & $\mathbf{N}$ & & & \\
\hline 48 & B2 & Ock & $\mathrm{CH}$ & -65 & 85 & $s$ & 24 & 39 & $S$ \\
\hline 48 & $\mathrm{B2}$ & OCk & $\mathrm{CH}$ & 0 & 65 & $\bar{w}$ & & & \\
\hline 48 & B2 & OCk & $\mathrm{CH}$ & 30 & 62 & $N$ & & & \\
\hline 49 & B2 & OCk & DOUCH & & & & 15 & 45 & 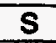 \\
\hline 50 & $\overline{B 2}$ & Ock & $\mathrm{CH}$ & & & & 30 & 35 & $s$ \\
\hline 51 & $B 2$ & $O C k$ & LS & & & & 26 & 41 & 5 \\
\hline 52 & B2 & $\infty \mathrm{Ck}$ & LS & & & & 30 & 21 & 5 \\
\hline 53 & B2 & OCk & $\mathrm{DOL}$ & & & & 31 & 21 & s \\
\hline 54 & B2 & OCk & $\mathrm{CH}$ & 65 & 59 & $\mathbf{N}$ & 36 & 41 & $s$ \\
\hline 54 & B2 & $\alpha_{k}$ & LS & -40 & 90 & $\bar{N}$ & & & \\
\hline 55 & B2 & OCk & $\mathrm{CH}$ & & & & 42 & 41 & $\mathbf{s}$ \\
\hline 56 & B2 & OCk & $\overline{D O L}$ & & & & 25 & 35 & $s$ \\
\hline 57 & $\overline{B 2}$ & OCk & $\mathrm{DOL}$ & & & & 40 & 60 & $s$ \\
\hline 58 & C1 & OCk & $\mathrm{CH}$ & & & & -81 & 22 & $s$ \\
\hline 59 & B1 & $\alpha_{k}$ & $\mathrm{CH}$ & & & & 81 & 45 & $\bar{s}$ \\
\hline 60 & D2 & Och & LS & & & & -80 & 15 & $s$ \\
\hline 61 & D2 & Och & LS & -45 & 85 & $N$ & -87 & 15 & $s$ \\
\hline 61 & D2 & Och & LS & 2 & 90 & $\mathbf{N}$ & & & \\
\hline 62 & D2 & Och & LS & & & & 86 & 24 & $\bar{s}$ \\
\hline 63 & D2 & Och & LS & & & & 81 & 21 & 5 \\
\hline 64 & D2 & Och & LS & & & & -86 & 21 & $\mathbf{s}$ \\
\hline 65 & C2 & Och & LS & 36 & 75 & s & 39 & 20 & $\mathbf{N}$ \\
\hline 66 & $\mathrm{C}_{2}$ & Och & LS & & & & 51 & 47 & $\mathbf{s}$ \\
\hline 67 & C3 & Och & LS & & & & -39 & 4 & $\mathbf{N}$ \\
\hline 68 & CB & Och & LS & & & & -75 & 25 & $\mathbf{N}$ \\
\hline 69 & CS & Och & LS & & & & -50 & 28 & $\bar{N}$ \\
\hline 70 & CB & Och & LS & & & & -31 & 31 & $\mathbf{N}$ \\
\hline 71 & C3 & Och & LS & & & & -67 & 30 & $S$ \\
\hline 72 & $C_{3}$ & Och & LS & & & & 5 & 25 & $s$ \\
\hline 73 & $\mathrm{CS}_{3}$ & Och & LS & & & & 25 & 15 & $\mathbf{s}$ \\
\hline 74 & $\mathrm{CB}$ & Och & LS & & & & 0 & 17 & $\bar{w}$ \\
\hline 75 & $\mathrm{CO}$ & Och & LS & & & & 40 & 14 & $\mathbf{N}$ \\
\hline 76 & C3 & Och & LS & -70 & 85 & S & -35 & 19 & $\mathbf{N}$ \\
\hline 76 & $C_{3}$ & Och & LS & -50 & 90 & $N$ & & & \\
\hline 76 & CS & Och & LS & -15 & 79 & $\mathrm{~s}$ & & & \\
\hline 77 & C3 & Och & LS & & & & -55 & 24 & $\mathbf{N}$ \\
\hline 78 & C3 & Och & LS & -10 & 75 & 5 & -60 & 25 & $\mathbf{N}$ \\
\hline 78 & $C 3$ & Och & LS & 35 & 90 & $\bar{N}$ & & & \\
\hline 79 & D2 & Och & LS & & & & 25 & 80 & $\mathbf{N}$ \\
\hline 80 & $\mathrm{D} 2$ & Och & LS & & & & 20 & 24 & 5 \\
\hline 81 & $C 3$ & Och & LS & -17 & $\infty 0$ & $\mathbf{N}$ & 76 & 44 & 5 \\
\hline 81 & C3 & Oach & LS & 76 & 69 & $\mathrm{~N}$ & & & \\
\hline 82 & C3 & Och & LS & -60 & 80 & $\mathbf{N}$ & 70 & 36 & $\bar{s}$ \\
\hline 82 & $C_{3}$ & Och & LS & 60 & 90 & $\mathbf{N}$ & & & \\
\hline 83 & C3 & Och & LS & -10 & 70 & S & 70 & 74 & $\mathbf{S}$ \\
\hline 84 & C3 & Och & LS & & & & 60 & 60 & $\mathbf{S}$ \\
\hline 85 & $C_{3}$ & Och & LS & -10 & 81 & 5 & 50 & 46 & s \\
\hline 85 & $C_{3}$ & Och & LS & 80 & 52 & $\mathbf{N}$ & & & \\
\hline 85 & C3 & Och & LS & 30 & 85 & $s$ & & & \\
\hline 86 & C3 & Och & LS & & & & 70 & 50 & 5 \\
\hline 87 & $\overline{C B}$ & Och & LS & & & & 62 & 44 & $\mathbf{N}$ \\
\hline 88 & C3 & Och & LS & .72 & 82 & $S$ & 66 & 21 & $N$ \\
\hline 89 & $C_{3}$ & Och & LS & -44 & 90 & $\bar{N}$ & 85 & 30 & $\mathbf{N}$ \\
\hline 90 & C.3 & Och & LS & & & & 60 & 47 & $S$ \\
\hline 91 & C3 & Och & LS & & & & 74 & 51 & 5 \\
\hline
\end{tabular}


42

Table A.1 (continued)

\begin{tabular}{|c|c|c|c|c|c|c|c|c|c|}
\hline & & & & \multicolumn{3}{|c|}{ FRACTURE } & \multicolumn{3}{|c|}{ BEDROCK } \\
\hline STATION & GRID & ROCK UNIT & LTHOLOGY & STAIKE & DIP & DD & STAKKE & DIP & DD \\
\hline 93 & CO & Och & LS & 15 & 68 & $N$ & 62 & 46 & s \\
\hline 94 & C3 & Och & LS & & & & 61 & 59 & s \\
\hline 95 & cos & Och & LS & & & & 62 & 60 & s \\
\hline 96 & $C_{4}$ & Och & LS & 16 & 51 & $N$ & 51 & 20 & $\bar{s}$ \\
\hline 96 & C4 & Och & LS & -56 & 70 & $N$ & & & \\
\hline 97 & B4 & Och & LS & 50 & 66 & $\mathrm{~N}$ & 64 & 35 & $\mathbf{s}$ \\
\hline 97 & 84 & Och & LS & -40 & 76 & $\mathbf{N}$ & & & \\
\hline 88 & B4 & Och & LS & 29 & 60 & $\mathbf{N}$ & 50 & 37 & 5 \\
\hline 98 & B4 & Och & LS & -55 & 90 & $\mathrm{~N}$ & & & \\
\hline 99 & 84 & Och & LS & 50 & 65 & $\mathrm{~N}$ & 55 & 31 & s \\
\hline 100 & $B 4$ & Och & LS & & & & 60 & 42 & $\mathbf{s}$ \\
\hline 101 & B4 & Och & LS & & & & 61 & 28 & s \\
\hline 102 & $B 4$ & OCk & DOL & & & & 60 & 25 & s \\
\hline 103 & BA & OCk & DOL & & & & 60 & 31 & $\mathbf{s}$ \\
\hline 104 & B4 & OCk & $\mathrm{DOL}$ & & & & 59 & 32 & $\bar{s}$ \\
\hline 105 & B4 & Och & LS & & & & 46 & 25 & 5 \\
\hline 106 & $B 4$ & Och & LS & .71 & 64 & $\mathbf{N}$ & 60 & 41 & 5 \\
\hline 106 & B4 & Och & LS & -50 & 90 & $\mathrm{~N}$ & & & \\
\hline 107 & $B 4$ & Och & LS & & & & 71 & 31 & $\bar{s}$ \\
\hline 108 & B4 & Och & LS & 86 & 69 & $\mathbf{N}$ & 61 & 30 & $\overline{\mathbf{s}}$ \\
\hline 108 & $B 4$ & Och & LS & -44 & 90 & $\mathbf{N}$ & & & \\
\hline 109 & B5 & Och & LS & & & & 74 & 30 & 5 \\
\hline 110 & B5 & ach & LS & & & & 70 & 25 & $\bar{s}$ \\
\hline 111 & $B 5$ & Och & LS & & & & 61 & 30 & s \\
\hline 112 & $\mathrm{CA}$ & Och & LS & -31 & 90 & $\mathbf{N}$ & 65 & 38 & $\mathbf{N}$ \\
\hline 113 & $C_{4}$ & $\alpha_{c h}$ & $\overline{L S}$ & & & & 75 & 34 & 5 \\
\hline 114 & $C_{4}$ & Och & LS & & & & 65 & 39 & $\mathbf{s}$ \\
\hline 115 & $C_{4}$ & Och & LS & & & & 71 & 44 & 5 \\
\hline 116 & $C_{4}$ & Och & LS & & & & 67 & 39 & S \\
\hline 117 & $C_{4}$ & Ch & LS & & & & 66 & 36 & $\bar{s}$ \\
\hline 118 & $C 4$ & Och & LS & & & & 64 & 41 & s \\
\hline 119 & $C_{4}$ & Och & LS & & & & 69 & 54 & s \\
\hline 120 & $C_{4}$ & Och & LS & & & & 66 & 49 & $s$ \\
\hline 121 & $\mathrm{CA}$ & Och & LS & 45 & 81 & $\mathbf{N}$ & 44 & 37 & 5 \\
\hline 121 & $C_{4}$ & Och & LS & -52 & 90 & $\mathbf{N}$ & & & \\
\hline 121 & $\mathrm{C}_{4}$ & Och & LS & -2 & 71 & 5 & & & \\
\hline 121 & $C_{4}$ & Och & LS & 90 & 57 & $\mathbf{N}$ & & & \\
\hline 122 & $c 4$ & och & LS & .76 & 69 & $N$ & 55 & 21 & 5 \\
\hline 123 & $C_{4}$ & Och & LS & 90 & 71 & $N$ & 36 & 39 & 5 \\
\hline 123 & $C_{4}$ & Och & LS & -86 & 84 & $\mathbf{N}$ & & & \\
\hline 124 & $\mathrm{CA}_{4}$ & Och & LS & & & & 24 & 22 & $\bar{s}$ \\
\hline 125 & $C_{4}$ & ach & LS & & & & 43 & 21 & s \\
\hline 126 & $C_{4}$ & Och & LS & -70 & 90 & $N$ & 69 & 29 & s \\
\hline 126 & $\overline{C 4}$ & Och & LS & -76 & 80 & $N$ & & & \\
\hline 126 & $\mathrm{CA}$ & Och & LS & -51 & 90 & $\mathbf{N}$ & & & \\
\hline 128 & $\mathrm{CA}_{4}$ & Och & LS & & & & 67 & 22 & $\mathrm{~s}$ \\
\hline 129 & C4 & $\alpha_{\text {ch }}$ & LS & & & & 61 & 20 & $\bar{s}$ \\
\hline 130 & C3 & Och & LS & & & & 59 & 32 & s \\
\hline 131 & $c 3$ & Och & LS & -25 & 76 & $s$ & 51 & 39 & s \\
\hline 131 & CO & Och & LS & 65 & 54 & $N$ & & & \\
\hline 131 & $C_{3}$ & Och & LS & 74 & 65 & $N$ & & & \\
\hline 131 & C3 & Och & LS & 74 & 56 & $\mathrm{~N}$ & & & \\
\hline 132 & $C 3$ & Och & LS & & & & 46 & 36 & $\mathrm{~s}$ \\
\hline 133 & C.3 & Och & LS & & & & 51 & 41 & $\bar{s}$ \\
\hline 134 & $c 3$ & Dch & LS & 40 & 54 & $\mathbf{N}$ & 42 & 34 & s \\
\hline 134 & C. & Och & LS & 45 & 69 & $N$ & & & \\
\hline
\end{tabular}


43

Table A.1 (continued)

\begin{tabular}{|c|c|c|c|c|c|c|c|c|c|}
\hline & & & & \multicolumn{3}{|c|}{ FRACTURE } & \multicolumn{3}{|c|}{ BEDROCK } \\
\hline STATION & GRID & ROCK UNIT & LTTHOLOGY & STRIKE & DIP & DD & STRIKE & DIP & DD \\
\hline 134 & C3 & Och & LS & -37 & 90 & $N$ & & & \\
\hline 135 & $\overline{B 3}$ & Och & LS & 44 & 51 & $\mathbf{N}$ & 41 & 36 & $\mathrm{~s}$ \\
\hline 135 & B3 & Och & LS & -41 & 90 & $\mathbf{N}$ & & & \\
\hline 136 & B3 & Och & LS & 82 & 64 & $N$ & 46 & 46 & $\mathbf{s}$ \\
\hline 136 & B3 & Och & LS & -30 & 87 & $\mathbf{N}$ & & & \\
\hline 137 & $\mathbf{B 3}$ & Och & LS & & & & 46 & 40 & $\mathbf{s}$ \\
\hline 138 & 83 & Och & LS & & & & 46 & 34 & $\mathbf{s}$ \\
\hline 139 & $\mathbf{B 3}$ & OCk & $\overline{D O L}$ & 47 & 40 & $\mathbf{s}$ & 46 & 42 & s \\
\hline 140 & $\mathrm{CB}_{3}$ & $\alpha_{\text {ch }}$ & LS & & & & 50 & 36 & $\mathbf{s}$ \\
\hline 141 & C3 & Och & LS & & & & 62 & 41 & $\mathbf{s}$ \\
\hline 142 & C3 & Och & LS & & & & 59 & 45 & $\mathrm{~s}$ \\
\hline 143 & CB & Oah & LS & & & & 61 & 42 & $\mathbf{s}$ \\
\hline 144 & C. & Och & LS & & & & 49 & 44 & $\mathbf{s}$ \\
\hline 145 & $c_{3}$ & Oan & LS & 90 & 81 & $\bar{N}$ & 50 & 41 & $\mathbf{s}$ \\
\hline 145 & CB & Och & LS & 35 & 81 & $\mathbf{N}$ & & & \\
\hline 146 & $\mathbf{C 3}$ & Och & LS & -70 & 84 & $\mathbf{N}$ & 56 & 26 & 5 \\
\hline 146 & $C_{3}$ & Och & LS & -74 & 54 & $\bar{N}$ & & & \\
\hline 147 & $C_{3}$ & Och & LS & 74 & 44 & $\mathbf{N}$ & 51 & 30 & $S$ \\
\hline 148 & B5 & OCk & $\overline{\mathrm{DOL}}$ & -31 & 81 & $\bar{N}$ & 54 & 31 & $S$ \\
\hline 148 & $\overline{B 5}$ & OCk & $\overline{\mathrm{DOL}}$ & 90 & 60 & $\bar{N}$ & & & \\
\hline 148 & B5 & OCk & $\overline{D O L}$ & -70 & 76 & $\mathbf{N}$ & & & \\
\hline 149 & 85 & OCk & $\mathrm{DOL}$ & -86 & 65 & $\mathbf{N}$ & 49 & 48 & $S$ \\
\hline 149 & $\mathrm{B5}$ & OCk & $\mathrm{DOL}$ & 80 & 60 & $\bar{N}$ & & & \\
\hline 150 & 85 & OCk & $\mathrm{DOL}$ & & & & 57 & 31 & $S$ \\
\hline 151 & 85 & OCk & $\overline{\mathrm{DOL}}$ & & & & 49 & 38 & S \\
\hline 152 & B5 & OCk & $\overline{\mathrm{DOL}}$ & & & & 54 & 41 & 5 \\
\hline 153 & B5 & OCk & $\mathrm{DOL}$ & & & & 51 & 37 & S \\
\hline 154 & B5 & OCk & $\mathrm{DOL}$ & 85 & 57 & $\mathbf{N}$ & 61 & 31 & $\mathbf{s}$ \\
\hline 155 & B5 & OCk & $\mathrm{DOL}$ & & & & 52 & 32 & 5 \\
\hline 156 & $\overline{B 5}$ & OCk & $\mathrm{DOL}$ & & & & 56 & 47 & 5 \\
\hline 157 & B5 & OCk & $\overline{\mathrm{DOL}}$ & 90 & 50 & $\mathbf{N}$ & 46 & 34 & $\mathrm{~S}$ \\
\hline 158 & B5 & Ock & $\mathrm{DOL}$ & & & & 62 & 33 & 5 \\
\hline 159 & B5 & OCk & $\mathrm{DOL}$ & & & & 59 & 32 & S \\
\hline 160 & B5 & OCK & $\mathrm{DOL}$ & & & & 54 & 34 & $S$ \\
\hline 161 & B5 & Och & LS & & & & 42 & 26 & 5 \\
\hline 162 & B5 & OCk & DOL. & & & & 62 & 46 & 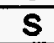 \\
\hline 163 & 85 & OCk & $\mathrm{DOL}$ & -36 & 75 & $\mathbf{S}$ & 57 & 39 & 5 \\
\hline 163 & B5 & OCk & $\mathrm{DOL}$ & -62 & 72 & $\mathbf{N}$ & & & \\
\hline 164 & B5 & OCk & $\mathrm{DOL}$ & 80 & 61 & $\mathbf{N}$ & 61 & 51 & S \\
\hline 165 & B5 & Och & LS & & & & 49 & 60 & 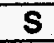 \\
\hline 166 & C5 & Och & LS & & & & 34 & 46 & 5 \\
\hline 167 & C5 & Och & LS & & & & 32 & 42 & s \\
\hline 168 & C5 & Och & LS & -69 & 71 & $\mathbf{N}$ & 59 & 29 & 5 \\
\hline 168 & C5 & Och & LS & -31 & 90 & $\mathbf{N}$ & & & \\
\hline 168 & C5 & Och & LS & -74 & 74 & $\mathbf{N}$ & & & \\
\hline 169 & C5 & Och & LS & & & & 56 & 30 & $\bar{s}$ \\
\hline 170 & C5 & Och & LS & & & & 60 & 36 & $\mathbf{s}$ \\
\hline 171 & C5 & Och & LS & & & & 56 & 47 & S \\
\hline 172 & B4 & OCk & $\overline{\mathrm{DOL}}$ & 40 & 69 & $\mathbf{N}$ & 58 & 41 & s \\
\hline 173 & $B 4$ & OCk & $\overline{D O L}$ & 49 & 81 & $\mathbf{N}$ & 45 & 39 & s \\
\hline 174 & $B 4$ & OCk & $\mathrm{DOL}$ & & & & 47 & 34 & $\bar{s}$ \\
\hline 175 & 84 & OCk & $\mathrm{DOL}$ & & & & 59 & 36 & $\mathrm{~s}$ \\
\hline 176 & B4 & Ock & $\mathrm{DOL}$ & & & & 61 & 31 & $\bar{s}$ \\
\hline 177 & D3 & Och & LS & & & & 54 & 24 & 5 \\
\hline 178 & D3 & Och & LS & 23 & 90 & $\mathbf{N}$ & 61 & 24 & $\mathbf{s}$ \\
\hline 178 & D3 & Och & LS & -77 & 81 & $\mathbf{N}$ & & & \\
\hline
\end{tabular}


44

Table A.1 (continued)

\begin{tabular}{|c|c|c|c|c|c|c|c|c|c|}
\hline & & & & \multicolumn{3}{|c|}{ FRACTURE } & \multicolumn{3}{|c|}{ BEDROCK } \\
\hline STATION & GRID & ROCK UNIT & UTHOLOGY & STRIKE & DIP & DD & STRIKE & DIP & DD \\
\hline 179 & D3 & $\alpha_{h}$ & LS & 51 & 84 & $\mathbf{N}$ & 36 & 20 & $\mathbf{s}$ \\
\hline 180 & D3 & Och & LS & 51 & 43 & $\mathbf{N}$ & 70 & 46 & $\mathbf{S}$ \\
\hline 181 & D3 & Och & LS & & & & 81 & 45 & $\mathbf{s}$ \\
\hline 182 & $\overline{D 3}$ & Och & LS & & & & 54 & 33 & $\bar{s}$ \\
\hline 183 & $\overline{D 3}$ & Oah & LS & 0 & 74 & W & 59 & 41 & $\mathbf{s}$ \\
\hline 183 & D3 & Och & LS & 45 & 60 & $\mathbf{N}$ & & & \\
\hline 184 & D3 & Ch & LS & 88 & $\infty$ & $N$ & 71 & 44 & $\mathbf{s}$ \\
\hline 185 & D3 & Och & LS & 82 & 45 & $\mathbf{N}$ & & & \\
\hline 185 & D3 & Och & LS & 35 & 83 & $\mathbf{s}$ & 68 & 36 & $\mathbf{s}$ \\
\hline 185 & D3 & Och & LS & 36 & 63 & $\bar{N}$ & & & \\
\hline 186 & D3 & Och & LS & -20 & 74 & $\mathbf{s}$ & 61 & 10 & $\mathbf{s}$ \\
\hline 186 & D3 & Oh & LS & 25 & 78 & $\bar{N}$ & & & \\
\hline 187 & D3 & Och & LS & & & & 56 & 62 & $\mathbf{N}$ \\
\hline 188 & D3 & Och & LS & & & & 76 & 31 & S \\
\hline 189 & D1 & Och & LS & & & & 50 & 10 & $s$ \\
\hline 190 & C2 & $\mathrm{OCK}$ & $\overline{\mathrm{DOL}}$ & & & & 25 & 14 & $\mathbf{s}$ \\
\hline 191 & $\mathbf{C 2}$ & OCk & $\overline{D O L}$ & & & & 35 & 15 & $\mathbf{s}$ \\
\hline 192 & $\mathrm{C}_{2}$ & OCk & $\overline{\mathrm{DOL}}$ & & & & 32 & 32 & s \\
\hline 193 & C2 & OCk & $\mathrm{DOL}$ & 31 & 90 & 5 & 46 & 28 & 5 \\
\hline 194 & $\mathrm{C2}_{2}$ & $O C k$ & $\overline{\mathrm{DOL}}$ & & & & 31 & 26 & 5 \\
\hline 195 & C2 & Och & LS & -12 & 81 & $\mathbf{s}$ & 11 & 31 & 5 \\
\hline 195 & $\mathrm{C2}$ & Och & LS & -51 & 90 & $\mathbf{N}$ & & & \\
\hline 195 & $\overline{C 2}$ & Och & LS & -74 & 79 & $\mathbf{N}$ & & & \\
\hline 196 & $\mathrm{C} 2_{2}$ & Och & LS & & & & 21 & 19 & $\mathbf{s}$ \\
\hline 197 & $\overline{\mathrm{D} 5}$ & $\mathrm{Cr}_{\mathrm{r}}$ & SS & & & & 60 & 51 & $S$ \\
\hline 198 & $\mathrm{D5}$ & $\mathrm{Cr}$ & SS & & & & 61 & 67 & $\mathbf{s}$ \\
\hline 199 & $\overline{\mathrm{D} 5}$ & $\mathrm{Cr}$ & SS & & & & 61 & 81 & 5 \\
\hline 200 & $\mathrm{D5}$ & $\mathrm{Cr}_{r}$ & $\overline{D O L}$ & & & & 82 & 79 & $\mathbf{s}$ \\
\hline 201 & C5 & OCk & $\overline{\mathrm{DOL}}$ & 0 & 80 & $\mathbf{w}$ & 75 & 69 & $\mathbf{N}$ \\
\hline 201 & $\overline{C 5}$ & $\overline{\mathrm{OCk}_{k}}$ & $\overline{D O L}$ & .71 & 61 & $\mathbf{N}$ & & & \\
\hline 201 & C5 & $\overline{O C k}$ & $\mathrm{DOL}$ & -61 & 90 & $\mathbf{N}$ & & & \\
\hline 201 & $\overline{C 5}$ & $\overline{O K}$ & $\mathrm{DOL}$ & -42 & 82 & $S$ & & & \\
\hline 202 & $\mathrm{C5}$ & $\infty \mathrm{Ck}$ & $\mathrm{DOL}$ & & & & 31 & 41 & $\mathbf{s}$ \\
\hline 202 & $\mathrm{C5}$ & OCk & $\overline{\mathrm{DOL}}$ & & & & 60 & 66 & 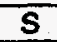 \\
\hline 203 & $\mathrm{CD}$ & OCK & $\mathrm{DOL}$ & & & & 80 & 31 & $s$ \\
\hline 204 & C5 & OCk & $\overline{\mathrm{DOL}}$ & & & & 60 & 46 & 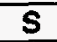 \\
\hline 205 & C5 & OCk & $\overline{\mathrm{DOL}}$ & & & & -80 & 70 & $\mathbf{N}$ \\
\hline 206 & C5 & $\overline{O C k}$ & $\overline{\mathrm{DOL}}$ & 19 & 72 & $\mathbf{N}$ & .74 & 56 & $N$ \\
\hline 207 & C5 & OCk & $\overline{\mathrm{DOL}}$ & 31 & 46 & 5 & -71 & 51 & $\mathbf{N}$ \\
\hline 207 & C5 & OCk & $\mathrm{DOL}$ & -19 & 81 & $S$ & & & \\
\hline 208 & C7 & Och & LS & & & & -10 & 28 & $\mathbf{N}$ \\
\hline 209 & $\mathrm{B3}$ & OCk & $\mathrm{DOL}$ & -63 & 79 & $\mathbf{N}$ & 66 & 34 & $\mathbf{s}$ \\
\hline 209 & $\mathrm{B3}$ & $\mathrm{COk}_{k}$ & $\mathrm{DOL}$ & -82 & 79 & $\mathbf{N}$ & & & \\
\hline 209 & $\mathrm{~B} 3$ & $\overline{O C k}$ & $\overline{\mathrm{DOL}}$ & .71 & 61 & $\bar{N}$ & & & \\
\hline 208 & 83 & OCK & $\mathrm{DOL}$ & 30 & 62 & $\bar{N}$ & & & \\
\hline 209 & $\overline{B 3}$ & $\overline{O C K}$ & $\mathrm{DOL}$ & -46 & 86 & 5 & & & \\
\hline 209 & $\overline{B 3}$ & OCk & $\mathrm{DOL}$ & 39 & 49 & $\mathbf{N}$ & & & \\
\hline 210 & $\mathrm{B3}$ & OCk & $\mathrm{DOL}$ & -51 & 76 & $N$ & 34 & 34 & $\mathbf{s}$ \\
\hline 211 & $\mathrm{B3}$ & $\mathrm{OCk}$ & $\mathrm{DOL}$ & & & & 51 & 36 & 5 \\
\hline 212 & $\overline{B 3}$ & OCk & $\mathrm{DOL}$ & & & & 32 & 46 & $\bar{s}$ \\
\hline 213 & 83 & $\overline{O C k}$ & $\mathrm{DOL}$ & & & & 31 & 34 & $\mathbf{s}$ \\
\hline 214 & $\mathrm{B3}$ & OCk & $\overline{D O L}$ & & & & 48 & 44 & $\mathbf{S}$ \\
\hline 215 & $B 3$ & OCk & $\overline{\mathrm{DOL}}$ & & & & 61 & 32 & $\mathbf{s}$ \\
\hline 216 & B3 & $\overline{O C k}$ & $\overline{D O L}$ & -34 & 78 & $\mathbf{N}$ & 51 & 36 & $\mathbf{s}$ \\
\hline 216 & $\mathrm{B3}$ & OCk & $\mathrm{DOL}$ & 79 & 66 & $\mathbf{N}$ & & & \\
\hline 216 & $\mathrm{B3}$ & $\overline{O K k}_{k}$ & $\overline{\mathrm{DOL}}$ & -69 & 79 & $\mathbf{N}$ & & & \\
\hline
\end{tabular}


45

Table A.1 (continued)

\begin{tabular}{|c|c|c|c|c|c|c|c|c|c|}
\hline & & & & \multicolumn{3}{|c|}{ FRACTURE } & \multicolumn{3}{|c|}{ BEDROCK } \\
\hline STATION & GRID & AOCK UNIT & LTHOLOGY & STRIKE & DIP & $\overline{D D}$ & STAIKE & DIP & DD \\
\hline 216 & $\mathrm{B3}$ & $\infty \mathrm{Ck}$ & $\overline{D O L}$ & 46 & 56 & $\mathbf{N}$ & & & \\
\hline 217 & 83 & $\infty_{k}$ & $\overline{D O L}$ & & & & 60 & 43 & $\mathbf{s}$ \\
\hline 218 & 83 & $\infty_{k}$ & $\overline{\mathrm{DOL}}$ & -54 & 81 & $\mathbf{N}$ & 40 & 36 & $\mathrm{~s}$ \\
\hline 219 & $B 3$ & $\infty c_{k}$ & $\mathrm{DOL}$ & 46 & 54 & $\mathbf{N}$ & 30 & 34 & $s$ \\
\hline 219 & B3 & $\infty k$ & $\mathrm{DOL}$ & -9 & 54 & 5 & & & \\
\hline 220 & $\overline{B 3}$ & $\infty_{k}$ & $\mathrm{DOL}$ & & & & 46 & 44 & 5 \\
\hline 221 & C6 & Och & LS & & & & 66 & 39 & s \\
\hline 222 & B6 & Och & LS & & & & 64 & 30 & $\mathbf{s}$ \\
\hline 223 & 86 & Och & LS & & & & 60 & 35 & S \\
\hline 224 & B6 & Och & LS & & & & 51 & 32 & s \\
\hline 225 & 86 & Och & LS & -61 & 78 & $\mathbf{N}$ & 45 & 34 & 5 \\
\hline 225 & B6 & Och & LS & 55 & 47 & $\bar{N}$ & & & \\
\hline 226 & B6 & Och & LS & & & & 45 & 32 & s \\
\hline 227 & $\overline{B 6}$ & oct & LS & & & & 47 & 49 & 5 \\
\hline 228 & B6 & Och & LS & & & & 46 & 37 & 5 \\
\hline 229 & $\overline{B 6}$ & Och & LS & 45 & 61 & $\mathbf{N}$ & 44 & 36 & $\mathbf{s}$ \\
\hline 230 & B5 & OCk & $\overline{D O L}$ & & & & 55 & 32 & s \\
\hline 231 & $\overline{B 5}$ & Och & LS & & & & 55 & 32 & $\mathbf{s}$ \\
\hline 232 & B5 & Och & LS & & & & 54 & 37 & 5 \\
\hline 233 & $\overline{B 5}$ & Och & LS & & & & 56 & 42 & s \\
\hline 234 & B5 & Och & LS & & & & 54 & 24 & $\mathbf{S}$ \\
\hline 235 & 85 & Och & LS & & & & 61 & 34 & $\mathbf{S}$ \\
\hline 236 & $\mathrm{B5}$ & $O C K k_{k}$ & $\overline{\mathrm{DOL}}$ & & & & 71 & 34 & $\mathbf{s}$ \\
\hline 237 & $\overline{B 5}$ & OCk & $\mathrm{DOL}$ & & & & 51 & 44 & $s$ \\
\hline 238 & 85 & OCk & $\mathrm{DOL}$ & & & & 44 & 39 & 5 \\
\hline 239 & D5 & $\mathrm{C}_{\mathrm{r}}$ & SS & & & & -10 & 15 & $\mathbf{s}$ \\
\hline 240 & C5 & $\mathrm{Cr}_{\mathrm{r}}$ & SS & & & & 72 & 69 & $\mathbf{N}$ \\
\hline 241 & C5 & $\mathrm{Cr}$ & SS & & & & 90 & 51 & $\mathbf{N}$ \\
\hline 242 & $\mathrm{C5}$ & $\mathrm{Cr}_{\mathrm{r}}$ & $\mathbf{S S}$ & & & & 82 & 85 & $\mathbf{N}$ \\
\hline 243 & C5 & $\mathrm{Cr}_{r}$ & SS & & & & 86 & 72 & $\bar{N}$ \\
\hline 244 & $\mathbf{C 1}$ & $\infty_{k}$ & $\overline{\mathrm{DOL}}$ & & & & 40 & 22 & 5 \\
\hline 245 & $C_{1}$ & $\mathcal{C K k}$ & $\mathrm{DOL}$ & -29 & $\infty 0$ & $\mathbf{N}$ & 51 & 24 & 5 \\
\hline 246 & D1 & Och & LS & & & & 55 & 27 & $\mathbf{S}$ \\
\hline 247 & $D 1$ & Och & LS & & & & 50 & 28 & $\mathbf{s}$ \\
\hline 248 & $D 1$ & Och & LS & & & & 52 & 30 & 5 \\
\hline 249 & $\overline{D 2}$ & $\mathrm{Cr}$ & SS & & & & 65 & 45 & 5 \\
\hline 250 & $E 2$ & Cop & SH & & & & 28 & 34 & $\mathrm{~s}$ \\
\hline 251 & $D 4$ & Och & LS & & & & 75 & 54 & $\mathbf{N}$ \\
\hline 252 & $\mathrm{D4}$ & $\alpha_{\text {ch }}$ & LS & -46 & 90 & $\mathbf{N}$ & 42 & 50 & 5 \\
\hline 253 & 04 & Och & LS & & & & 75 & 51 & 5 \\
\hline 254 & 85 & OCk & $\overline{\mathrm{DOL}}$ & & & & 41 & 22 & 5 \\
\hline 255 & B5 & OCk & $\mathrm{DOL}$ & & & & 56 & 45 & 5 \\
\hline 256 & B5 & OCk & $\overline{\mathrm{DOL}}$ & & & & 48 & 41 & 5 \\
\hline 257 & B5 & $\alpha_{k}$ & $\overline{\mathrm{DOL}}$ & & & & 80 & 32 & 5 \\
\hline 258 & $\overline{B 5}$ & Och & LS & & & & 57 & 39 & $\bar{s}$ \\
\hline 259 & $\overline{B 5}$ & Och & LS & & & & 44 & 37 & 5 \\
\hline 260 & $\mathrm{B5}$ & Och & LS & & & & 58 & 36 & 5 \\
\hline 261 & $\overline{A 5}$ & OCk & $\overline{D O L}$ & 81 & 59 & $\mathbf{N}$ & 39 & 42 & S \\
\hline 262 & A5 & OCK & $\mathrm{DOL}$ & & & & 48 & 46 & 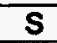 \\
\hline 263 & $\overline{A 5}$ & OCk & $\mathrm{DOL}$ & & & & 51 & 38 & s \\
\hline 264 & $C_{3}$ & Och & LS & -5 & 82 & 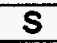 & 70 & 39 & $\mathbf{s}$ \\
\hline 265 & $C_{3}$ & Och & LS & & & & 66 & 26 & $\mathbf{N}$ \\
\hline 266 & $C_{3}$ & Och & LS & & & & -11 & 10 & $\bar{N}$ \\
\hline 267 & C3 & Och & LS & & & & 39 & 31 & $\mathbf{N}$ \\
\hline 268 & C3 & Och & LS & & & & 61 & 12 & $\mathbf{N}$ \\
\hline 269 & $C_{3}$ & Och & LS & & & & -80 & 59 & $S$ \\
\hline
\end{tabular}


46

Table A.1 (continued)

\begin{tabular}{|c|c|c|c|c|c|c|c|c|c|}
\hline & & & \multicolumn{3}{|c|}{ FRACTURE } & \multicolumn{3}{|c|}{ BEDROCK } \\
\hline STATION & GRID & ROCK UNIT & LITHOLOGY & STRIKE & DIP & DD & STRIKE & DIP & DD \\
\hline 270 & C3 & OCh & LS & & & & 75 & 35 & N \\
\hline 271 & C3 & OCh & LS & & & & 45 & 41 & N \\
\hline 272 & D2 & OCh & LS & & & & 50 & 29 & S \\
\hline 273 & D2 & OCh & LS & & & & 60 & 67 & N \\
\hline 274 & D2 & OCh & LS & & & & 64 & 21 & S \\
\hline 275 & D2 & OCh & LS & & & & 61 & 24 & S \\
\hline
\end{tabular}


Appendix B

\section{GEOLOGIC MAP OF THE OAK RIDGE K-25 SITE AREA}


48

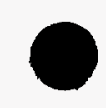

- 
K/ER-111

\section{DISTRIBUTION}

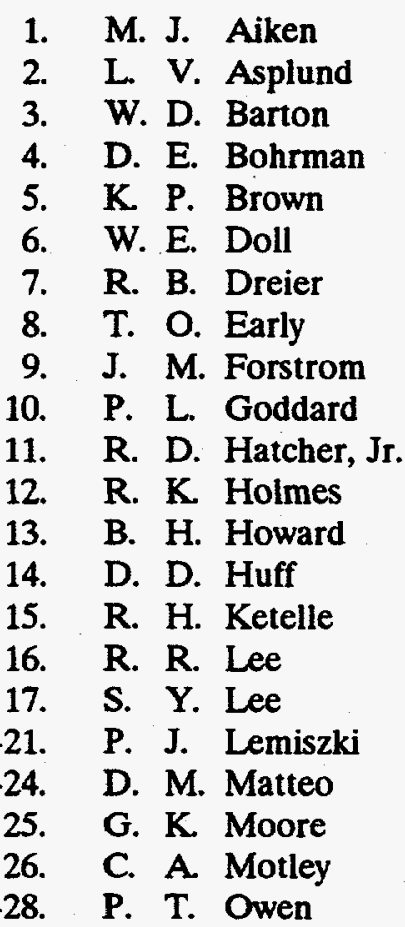

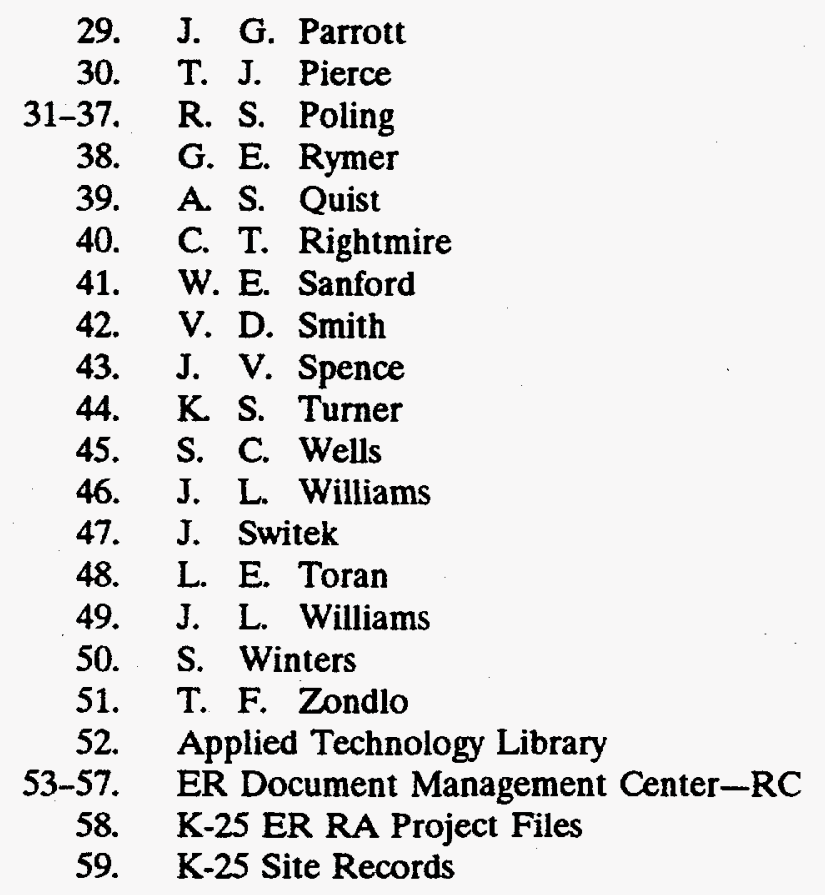

60-63. R. Arnseth, Science Applications International Corporation, 301 Laboratory Road, Oak Ridge, TN 37830

64. P. E. Barndt, Department of Energy, Oak Ridge Operations Office, P.O. Box 2001, Oak Ridge, TN 37831

65-69. G. W. Bodenstein, Department of Energy, Oak Ridge Operations Office, P.O. Box 2001, Oak Ridge, TN 37831

70. D. A. Lietzke, Lietzke Soil Services, Route 3, Box 607, Rutledge, TN 37861

71. M. A. Travaglini, Manager, K-25 Environmental Restoration Program, Department of Energy Oak Ridge Operations Office, P. O. Box 2001, Oak Ridge, TN 37831 
NOTICE

Page(s) size did not permit electronic reproduction. Information may be purchased by the general public from the National Technical Information Service, U.S. Department of Commerce, Springfield, VA 22161 (Area Code 703-487-4650). DOE and DOE contractors may purchase information by contacting DOE's Office of Scientific and Technical Information, P.O. Box 62, Oak Ridge, TN 37831, Attn: Information Services (Area Code 423-576-8401). 